\title{
Tyske Fremstillinger af Sønderjyllands Nationalitet efter 1896.
}

Udtog af Forelæsninger,

holdt ved Aarhus og Kjøbenhavns Universiteter i 1938 af Gudmund Schüt te.

Tidsrummet omkring 1848 præges paa tysk Side af Sprogmanden Jacob Grimms politisk farvede Annexionisme; den støttedes af Dr. Daniels i indtil ca. 200 Oplag udkommende Skolegeografier, der kort og godt fremstillede Danmark som et "tysk Udenland" med "lutherske" (!) Indbyggere. Jfr. hans Sætning i Bogen "Deutschland «: "Tysklands nordligste Punkt er Skagens Horn«.

Efter at Annexionen af Sonderjylland lykkelig var gennemført i 1864, faldt man i Tyskland til Ro, naar bortsees fra Fuskeren Dr. Clements annexionistiske Makværk i 1869, som pulveriseredes af Prof. Vilh. Thomsens Modindlæg i »Literarisches Centralblatt«. Se herom Artikler af mig i "Flensh. Avis« 30.-31. 5. 1912, 1. 6. 1912, "Berl. Tid.« Aft. 23. 7. 1912.

Saa kommer Udjagning af det danske Sprog fra Nordslesvigs Skoler i 1888, der ganske naturlig sætter Fart i Agitationen paa begge Sider. Det er næppe tilfældigt, at netop 1889 startes paa dansk Side "Sønderjydske Aarbøger«, og 1890 folger det slesvig-holstenske Hjemstavnstidsskrift "Die Heimat«.

1892 drager Prof. Gerland foregribende Konsekvensen af Skolernes Fortyskning, idet han i "Atlas der Völkerkunde" fremstiller Sønderjylland som tysktalende indtil Kongeaaen! Lkyndige engelske Korttegnere som $\mathrm{Mr}$. Bartholomew og Prof. Roberts on kopierer Gerlands usandfærdige Kort i deres af Oxford Universitet udgivne Atlanter lige indtil 1928, da det endelig lykkes mig at faa dette Uvæsen stoppet.

Om Dommer J. G. C. A d l e rs "Volkssprache in dem Hzgt. Schleswig seit 186i«" (1891) henviser jeg til Mag. H. V. Clausens Kritik i "Sønderj. Aarb.« 1892, og i Fr. v. Jessens »Haandbog", S. 337. 
Hele det her skitserede ældre Tidsrum 1848-1892 skal jeg ellers lade ligge, idet jeg blot henviser til Fremstillingen i min Bog "Altyske Annexionslærdomme om dansk Land og Folk", 1909. Ganske vist kunde jeg ønske i en særskilt Artikel at give en Generaloversigt over Artiklerne i "Die Heimat" for derved at kaste Lys over den Askepotstilling, som Nordslesvig indtager i den slesvig-holstenske literære Praxis; men det faar nu vente.

Iøvrigt vælger jeg mit Udgangspunkt ved Aaret 1896, da Titulærprofessor Overlærer A u g. S a c h tog fat paa at udgive sit tykke etnologisk-statistiske Værk "Das Herzogtum Schleswig", afsluttet 1907. Aaret 1896 ligger nemlig tret op ad Aaret 1898, der efter 1888 er det næste Mærkeaar i Sønderjyllands Nationalitetshistorie, den köllerske Danskerforfølg e l s e s Indlednings-Aar. At Hr. Sachs Værk var Led i en stort anlagt Aktion, fremgaar deraf, at det nød Understøttelse af Landsdirektoratet for Slesvig-Holsten og Provinsiallanddagen, og at $\mathrm{Bd}$. III var tilegnet Den Tyske Forening for det Nordlige Slesvig. I Værket, som indeholder en Mængde værdifuldt historisk-geografisk Stof, drager Forf. uafladelig til Felts mod Paastanden om Sønderjydernes Danskhed, denne Lære, som han paa et Filologmøde i Neumünster 1910 stemplede som en "forgiftende Vranglære«. Det samme gør han som Medarbejder ved Prof. Langh a n s' nationalistiske Tidsskrift "Deutsche Erde" (stiftet 1902). Sach hævder, at naar Sønderjyderne kaldes danske, gælder det kun i "politisk " Mening; og hvor han i ældre Literatur finder Udtrykket »dansk « brugt om Sønderjyder $i$ national Mening, sætter han det systematisk i Gaaseøjne! I, S. 11 hedder de f. Ex.: "Overalt, hvor Navnet dansk forekommer, har det en svag Bismag, der peger hen paa en særegen Oprindelsesart. Dertil hører Navnet "Steertdänen“ (Haledanskere), som de nær Byen Slesvig boende og vestjysktalende Landfolk ved den daværende Sproggrænse endnu paa den slesvigske Historiker Ulrich Peterselıs Tid († 1735) »in aller Kurzweil " (»i al Gemytlighed () maatte fore; endvidere det spottende Udtryk "Wurzeldänisch" ("Wötteldänisch, Roddansk), som gaves Sproget hos de østlige angelske Herreders Landfolk, fordi de bragte »Rød- 
der" og Roer til Torvs, eller Navnet "Smeerdänen« (Smørdanske), hvoermed man drillede Indbyggerne nord for Flensborg Pointen i denne Fremstilling er aabenbart den Opfattelse, at "die Steertdänen«, "Svansdanskerne«, paa. Grund af deres ikke ægte Danskhed fik et Smædenavn, der omtrent stillede dem paa Linie med "Halenegre» og deslige "minderwertige Rassen«. Her er Hr. Sach imidlertid i sin tendensiøse Danskfjendtlighed kommen for Skade at sige noget indlysende Vrøvl. Det spøgefulde Navn »Steertdänen«, "Svansdanskere«, har aldeles intet at gøre med en foragtelig Kendemærkning af ikke-dansk Nationalitet. Man har simpelthen omtydet Navnet paa Halvøen Svansø, som om det var "Svans og ombyttet det med Synonymet "Stjært". Den Slags Ombytninger er overmaade gængse ved folkelige Øgenavne; f. Ex. kaldes Næsboerne paa Mors for "Snudeboer«, Ekshärads Indbyggere i Götland for "Sexøringer" o. desl. - Det virkelige, som Navnet "Steertdänen« lærer os, $\in$ r da, at Svansboerne er bleven opfattede som Danske; altsaa gaar Vidnesbyrdet lige stik imod det, som Hr. Sach vil dreje det om til. Jeg skal ikke nærmere i Enkeltheder her indlade mig paa Hr. Sachs Fremstilling, da jeg udførlig har gendrevet den i Artiklen "Altysk "Sprogvidenskab«", trỵt i "Flensborg Avis« og "Hejmdal« 15. 12. 1910 ff. I Afdeling IV gør jeg opmærksom paa, at Hr. Sach citerer en hel Rrkke Vidnesbyrd om, at Udtrykket "dansk" i folkelig Sprogbrug har været brugt om Sønderjydernes Sprog og Nationalitet, medens han ikke evner at fremlægge et eneste Exempel paa Brug af Ucltrykket "jysk«. Hertil kan føjes, at Aabenraa Byskraa skelner mellem »dansk og fremmed $\emptyset 1 \lll$, altsaa udtrykkelig kendemærker det danske som det hjemlige. I Afd. II paaviser jeg, at $\mathrm{Hr}$. Sach har brugt en Række Sætninger fra min Artikel »Var Anglerne Tyskere?" ("Sønderj. Aarbøger» 1900), idet han i sin Bog

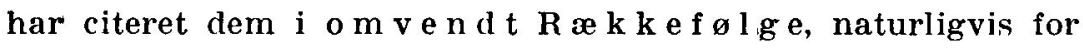
at maskere "Laanet". Denne Brug af laant Stof stemplede jeg som Plagiat, og jeg har ogsaa senere gentaget min Plagiatsigtelse. Hr. Sach foretrak "sich auszuschweigen«, at tie bom- 
stille, og saaledes har han gjort overfor alle følgende Afsløringer af hans dilettantiske Paastandes Hulhed.

Indtil Slutningen af 1910 havde han imidlertid Fred til at tumle sig af Hjærtens Lyst, og det gjorde han ogsaa, saa det forslog noget. I 1909, uden Tvivl paa hans Tilskyndelse, indgik nemlig den Tyske Forening til det Statistiske Kontor i Berlin med Forslag om, at der ved fremtidige Folketællinger skulde gøres Skel mellem "Danske« og »Jyder«!! »Itzehoer Nachrichten« (populært kaldet "Stormklokken«), som bragte Meddelelsen, tilføjede triumferende: "Det er paa Tide, at Videnskaben kommer til sin Ret«.

Den her forsøgte Aktion er bleven omtalt af mig forskellige Steder, men den er af den danske Regering, det danske Universitet, det danske Folk langtfra bleven opfattet i sin fulde Forfærdelighed. En altysk Dilettant, der af sine »MedAnnexionister" udnævnes til "Videnskabsmand«, tillader sig her mir nix dir nix at ophæve den danske Nationalitets gennem tusind Aar uomstridt anerkendte Enhed! Han drager en Skillestreg, der vil Iøsrive Vestjyderne, ja, i sin fulde Konsekvens samtlige Jyder fra det danske Folk!!! Og den danske Regering, det danske Universitet, det danske Folk - - tier bomstille. Min egen Ringhed lades omtrent ene om at tage til Genmæle.

Under saadanne Forhold maa det regnes som et Mirakel, at Aktionen mislykkedes. Men det gjorde den. Berlin var for anstændig til at følge $\mathrm{Hr}$. Sach paa hans annexionistiske Vildmand. Stormklokken i Itzehoe gik Glip af den varslede Triumf. Man havde solgt Huden, før man havde Bjørnen.

1897 udgav E ckardt "Alt-Kiel in Wort und Bild«. Jeg nævner det her paa Grund af den sanddru Skildring af de sidste Gottorperes Vanstyre og Velsignelsen ved det kgl. danske Herredømme, - en skarp Modsæetning til de sædvanlige Jeremiader over dansk Erobring og Voldsstyre. Se min Artikel i "Sønderjydske Aarbøger« 1937, S. 213.

1899 udkom Prof. Ot t o B r e mers »Ethnographie der ger- 
manischen Stämme" i Pauls "Grundriss der germ. Philologie«, 2. Udg. Værket bringer adskilligt rigtigt. Forf. indrømmer $\mathrm{S}$. 856, at Nutidens Jyder taler en afgjort nordisk Dialekt, og S. 865 paaviser han ikketyske - engelske - Sprogrester hoș Saxerne i Nordhannover og Holsten. Men samtidig findes paafaldende Urigtigheder. F. Ex. vil Forf. S. 851 stedfæste den Anglerne nærstaaende Stamme Varnerne i det sønderjyske Varnæs, som han efter Müllenhoffs Forbillede gengiver paa Latin ved "promuntorium Varinorum" og yderligere forsyner med Aarstallet 1231, - dvs. han lader Læseren tro, at det latinske Navn findes i »Valdemars Jordebog«; ogsaa mig har han bl. a. narret dermed. Men dette "Kildecitat" er fri Fantasi af Bremer; den latinske Oversættelse er opfunden af Müllenhoff! Man maa iøvrigt nok spørge, om ogsaa de forskellige Varnæs i Norge og Sverige skal være varniske? Hele Skandinavien synes at have været oversvømmet af denne mærkelige Stamme.*) - S. 837 hedder det efter den tysk-danske Grænseoverenskomst 1026, hvorved Ejderen anerkendtes som Statsgrænse: "Men kun Halvøen Svans er bleven dansk Sprogomraade; det vestligere Landskab mellem Ejder og Trene forblev nedertysk «. "Forblev«??! At Egnen forud havde været det, er en i Luften frit svævende Paastand.

1900 udgav Østrigeren Prof. R u d. M u c h $\sin$ „Deutsche Stammeskunde« (3. Udg. 1920). Den undgaar langt mere end Bremer at udslynge mislige Paastande, men kommer kun lidet ind paa Jyllands gamle Indbyggere. S. 99 (3. Udg.): Jyderne $\mathrm{i}$ England maa efter deres Sprog have været Sydgermaner; i Jylland blev deres Efterkommere daniserede. Det sædvanlige altyske Litani om en voldelig dansk Erobring savines helt.

1901 fremkom Gloys "Beiträge zur Geschichte der Leibeigenschaft in Holstein«. Igen et Værk, der ikke kender til det fæle danske Voldsherredømme, men tværtimod roser de danske Kongers humane Styre (f. Ex. S. 79).

*) Forøvrigt har Prof. Sch e el i »Geschichte Schleswig-Holstein «S II, 76, nylig paapeget Vilkaarligheden ved at forbinde Varnæs med Varnerne; Navnet skal ganske sikkert skilles Var-næs og har intet med Varner at gøre. 
1909 indlededes Drøftelsen mellem Prof. Martin Rade og J o h s. T i e d j e paa den ene Side, Prof. Valdemar Ammundsen paa den anden, i Rades Tidsskrift "Die Christliche Welt", udg. paa Dansk af Ammundsen, jfr. Tiedje "Die Zustände in Nordschleswig«. Her ydes der dansk-sønderjysk Kultur Retfæraighed. Tiedje karakteriserer det lanske Kirkefolks Inderlighed ved Mottoet "Se, de beder!«, og tager ogsaa Afstand fra de dilettantiske Paastande om Sønderjyskens Ikkedanskhed.

I »Die Christliche Welt«, 1910, Nr. 3, omtaler han ogsaa velvillig min Bog "Altyske Annexionslæerdomme om dansk Land og Folk« og stempler Altyskerne som "Verdensfredens Anarkister h a rdt i "Jahresbericht üb. Erscheinungen auf d. Gebiet der germ. Philologie«, 1913, XIV, V, No. 156).

I 1911 vrimlede den tyske Presse i Nordslesvig med Indlæg af forskellige Ainonymer, N. S., dh., h d., etc., der alle vilde paavise "vestgermanske" Levninger i Sønderjysk. I »Vort Land", 16. Sept., og andensteds afslørede jeg Anonymerne ved at lægge Bogstaverne sammen; $\mathrm{N}(\mathrm{is}) \mathrm{S}(\mathrm{c}) \mathrm{h}(\mathrm{r} \theta) \mathrm{d}(\mathrm{er})$, altsaa Titulærprofessor $\mathbf{N}$ is S chroder. Derefter forelagde han Stridsspørgsmaalet for den kendte Anglist Prof. Th. Sie bs i Breslau, men fik her en knusende Afvisning. Siebs erklærede: "Den Antagelse, at der $i$ de slesvigske Distrikters Dialekt skulde findes Levninger fra Indbyggere, der skulde have boet her før Danskerne, lader sig ikke videnskabelig opretholde«. Yderligere gav han Hr. Schröder en Overhaling for en den videnskabelige Sandhedserkendelse næsten kvælende Chauvinisme. Og denne Voldgiftsdom maatte "Schleswigsche Grenzpost" 3. Oktober optage i sine Spalter.

1912 udgav A. J. L o r e n z e n Bogen "Unsere Heimat Nordschleswig«, et udpræget danskfjendtligt Værk. Det indeholder mest kulturelle og skønliterære Bidrag. Efter H of f, "Schleswig-Holsteinische Heimatgeschichte«, citeres et Stykke »Der Name des Landes und seiner Bewohner«. Deri gøres der efter kendt tysk Skik meget Væesen af, at Sønderjyderne en Tid lang kaldte sig Holstenere. Efter Henvisning til Sach siges der vi- 
dere: "Danskehar Indbyggernealdrigkaldt sig. *) Dette Navn forekommer kun i folkelige og spottende Udtryk, som f. Ex. "Steertdänen« som Navn for de vestjysktalende Landfolk ved Slesvig eller "Smeerdänen" (Smørdanskere) for Landfolket nord for Flensborg «. At denne sachske Visdom er helt forfejlet, har jeg allerede ovenfor paavist. - Iøvrigt undgaar $\mathrm{Hr}$. Lorenzen temmelig omhyggeligt at lade sige noget direkte om Folkesproget i Nordslesvig, og han meddeler, saavidt jeg kan se, ikke en eneste dansk Dialektprøve. Men desto mere arbejder han udfra den Tilsnigelse, at Nordfrisland regnes med til Nordslesvig. Han siger udtrykkelig i Forordet: "Ligesom jeg ved Afgrænsningen af $\mathrm{O} \mathrm{mra}$ a d t Nordslesvig ikke har ladet raade nogen Snæverhjertethed, saa har jeg heller ikke formaaet at gøre det ved Valget af Medarbejdere«. Nej, "engherzig" er han saa vist ikke, det skal han faa Attest for. Over Halvdelen af første Afdeling udgøres af Stykker om Nordfrisland eller af frisiske Forfattere. Der gives ogsaa et Digt paa Frisisk, - medens som sagt Nordslesvigs danske Folkemaal er lockoutet. Ja, paa Bindets Farvevignet sees en nordslesvigsk Bonde, der overfor en angribende dansk Ridder forsvarer sig under Løsenet: "Lever dod as slav!« (»Hellere død end Træl!«). Et frisisk Losen, oversat paa Plattysk! Og det paaduttes Nordslesvigeren! Som om Nordslesvigerens Sprog var Plattysk! Den gennemforte Usandfærdighed, hvormed Nordslesvig skal gøres til et halv-vestgermansk Blandingsland, kommer vel ingensteds tydeligere til Orde end gennem dette Humbugs-Lasen. Iøvrigt maa det tilføjes, at den ikke »engherzige" Udgiver meitager hele fire Stykker fra R. Mejborg, "Das Bauernhaus im Hzgt. Schleswig “ (overs. af Prof. Rich. Haupt). Den danske Forfatters udmærkede Vark bruges altsaa som passende Fyldekalk $i$ det danskfjendtlige Skrift. Heldigt er det for Hr. Lorenzen, at Mejborg var død og borte; ellers havde han sikkert energisk protesteret mod denme Misbrug af sit Værk. Nu har han altsaa maattet nøjes med at vende sig i sin Grav.

*) Fremhæuet af G. S-e. 
Ganske vist, Bogen indeholder ogsaa Afsnit, hvori dansk Kulturindflydelse paa Nordslesvig erkendes. Saaledes skriver Christen Gröndahl 144 ff. om Folkehøjskoler. Grundtvigs "geniale« Indsats erkendes. "Hans Folk skulde atter vorde nationaltı, osv., osv., fortælles der med honningsøde Ord. Hvorpaa Artiklen ender med en Skildring af Folkehøjskolerne Tinglev, Nørborg og Maarkjær, der er grundede med den udtrykkelige Hensigt at a $\mathrm{n}$ ationalise $\mathrm{n}$ (et samme Folk, altsaa er en Knytnæve i Synet paa Stifterens Aand. Nej, maa vi saa bede om Hjemmetyskere som Erich Schlaikier, der aabent erkender Fortysskningshøjskolen som det, den er: et Snigmordsforsøg mod Landets Odelsfolk.

Mere tiltalende end den ikke overdrevent ærlige Grundtvigdiscipels honningsøde Ord er det, naar Generalsuperintendent $K$ a f t a n oversætter Brorsons Digt "I denne søde Juletid «, og naar Jörgen Hansen i sin Skildring af Landvæsenet uden nogensomhelst Vaklen eller Tilsløring giver dansk Kulturindflydelse Eren for Nordslesvigs høje Standpunkt. Men saadanne enkelte Lyspunkter kan ikke hindre, at den danske Læser forlader Hr. Lorenzens Udgiverværk nærmest med Væmmelse.

1912 udgav Dr. P a u l H a m b r c h en "Landeskunde von Schleswig-Holstein« i "Sammlung Göschen« Nr. 563. Heri omtales S. 38 ff. Kartografen Ge e rz Forsøg paa ved Hjælp af Stednavne at efterspore de gamle Folkestammers Bosættelse, hvad Reimer Hansen siden 1902 har gennemført "grundigere«. I en Tabel fordeles Endelserne, som følger:

-lev tilhører Varnerne, -sted, -stedt Nordgermanerne, -ing Barderne, -um (-heim) Friser, Nordgermaner, -by Jyderne. -büll, -böll, -büttel Friser, Saxer. Der siges f. Ex. "by forekommer næsten kun i Angel og Nordfrisland. Endelsen -lev viser, at i gammel Tid hele Jylland og Slesvig-Holsten indehavdes af tyske Stammer; Bosættelserne paa -stedt, -um, -by tilskrives Jyderne, der efter Folkevandringen indtog de ledig blevne Egne. Andre Bosættelser af tysk Oprindelse ender paa -dorf, -torp, -trup, -drup, -rup; vi finder hinsides Elben i Hannover, West- 
falen, Oldenburg de samme Stednavne igen. Navne paa -holm, -kamp, -ho, -lo er af nedertysk Oprindelse. Jyske Bosættelser ender paa -lund, -vith, -by, stov«.

Det er overflødigt at spilde mange Ord paa dette forvirrede Sammensurium, der viser tysk Stednavnefuskeri i dets allerværste Form. Den forsøgte Fordeling af Endelser er som Helhed fuldkommen taabelig. Jfr. min Artikel i "Der Schleswiger" 2. Okt. 1926, "»Ortsnamenkunde« in der Sammlung Göschen«, hvor jeg har ofret min Tid paa nærmere at kaste Lys over det elendige Makværk.

1912 udgav Reimer Hansen (Oldeslohe) sin "Kurze Schleswig-Holsteinische Landesgeschichte«. Forf. er en afgjort Tilhænger af den ledende Antidansker Aug. Sach, men iøvrigt ret forsigtig i sine Udtalelser. Hans Skrift indeholder adskilligt at lægge Mærke til.

S. 3 anbringer han rigtig Kimbrerne i Himbersyssel. Men derefter følger smst. et ret uheldigt Stykke om Stednavnene paa -l e v, -l e b e n. "Stednavne paa -leben findes fra Skaane .. indtil Mellemslesvig og derpaa atter fra Altmark til Thüringer Wald i stort Tal. Alt taler for, at ogsaa denne Vandring maaske omkring 100 e. Kr. - gik fra Nord mod Syd; Varner og Angler har vel taget Del deri og maaske været Bærerne af hin Navneform«. Her følger Forf. aabenbart W. S e e l m a n n, der i »Jahrbuch f. niederdeutsche Sprachforschung “ 1886 tillægger Varnerne Endelsen -lev. Et mærkeligt Varnerfolk, der har hersket over hele Danmark, det halve Sverige og et Stykke af Norge, uden at det paa disse Steder har efterladt sig noget historisk Spor! - Diet skulde da være den af Seelmann fremdiagne Bygd Wassersleben ved Flensborg, der historisk viser sig at have Navn efter en $\mathrm{kgl}$. Justitsraad Waschersleben fra 18. Aarhundrede, - blot var han ikke varnisk, men dansk Høvding, og han levede ikke ved Aar 1780 f ø $\mathrm{r}$ Kristus, men e f t e $r$ Kristus. - Nu har Videnskaben forlængst kasseret Hr. Seemanns varniske Fantasiteori; saaledes ogsaa Prof. S c h e el, der i Skriftet "Schleswig - urdänisches Land?" uden nogen Vaklien afleder ogsaa de tyske Leben-Navne fra Danerne. Men 
indtil 1912 levede altsaa Reimer Hansen videre $i$ den gamle Vranglare.

S. 8 bliver Grænsedragningen ved Ejderen 811 omtalt uden Tilsløring, og det hedder videre meget objektivt, S. 10: „Ugrundet er det, at Henrik har skudt det tyske Riges Grænse frem til Slien og her oprettet en Grænsemark«. Forf. synes altsaa at have mærket sig Prof. Steenstrups Dokumentation i Afhandlingen "Danmarks Sydgrænse og Herredømmet over Holsten« (1900).

Endvidere nævnes, at Sysselinddelingen gjaldt baade for Slesvig og Jylland, og $\mathrm{S}$. 10 vrages Fablen om Kejser Otto I's Tog til Oddesund i Limfjorden. Objektivt hedder det videre S. 11: "Englands Indflydelse paa den nordiske Kirke overvejede under Knud det tyske Riges. Konrad II afstod 1026 Grænsemarken, der næppe mere havde nogen Vigtighed, til Knud. .. Derpaa tiltog ogsaa Tallet af jyske Nybyggere i Svans og Dänischwohld; først $\mathbf{i}$ senere Tid er Tyskheden bleven herskende ved Indvandring«. .... »1104 fik Lund i Skaane et Frkebispedomme; da ogsaa Bispedømmerne Ribe og Slesvig underlagdes det, var det kirkelige Baand, det eneste, der knyttede Slesvig og Holsten sammen, revet over«.

Altsaa en meget aabenhjertig Tilstaaelse af, at der ved 12. Aarh.s Gry endnu ingen Slesvig-Holsteinisme existerede!

Først fra 1115 af omtaler Forf. en diskret Stræben efter at forene Egnene paa begge Sider af Ejderen, som den kom til Orde gennem Knud Lavard.

Hidtil har der, bortseet fra den fejlagtige Opfattelse af Levtypen, egentlig ikke kunnet indvendes væesentligt mod Fremstillingen. Men fra 15. Aarh. af tager den en anden Farve.

S. 30 hedder det om Kejser Sigismunds Voldgiftsdom i Striden mellem Kong Erik af Pommern og de holstenske Grever om Herredømmet i Sønderjylland: "Støttet paa en Række mislige ("bedenkliche«) Vidnesbyrd freldede Sigismund den 25. Juni 1424 den Dom, at hele Sønderjylland med Dänischwohld 
og de frisiske Herreder tilhørte Kongen og Riget Danmark, og at der ikke tilkom Greverne nogen Ret."

Efter at have kigget i de bindstærke Procesakter tør jeg ikke anmasse mig at afgøre, om den ene eller den anden Parts Retsdokumentation er juridisk bindende. Een Ting er imidlertid sikker: for saa vidt som der er Tale om Folkets Ret, og dét var jo dog ogsaa Part i Sagen -, saa var det kun i Kong Eriks Aktorat, at der blev taget Hensyn dertil. Og Folket tav ikke stille; det svarede klart og grejt, gennem de sønderjyske Gejstliges og Borgeres Mund, 4. Aug. 1421: Sønderjylland hører til Danmark - statslig, retslig og sproglig. Dette er det danske "f or evig udel t«, som burde prentes med Guldbogstaver i Sønderjyllands Historie. Kongens Appel til Folkets Dom i Jylland, Skaane og paa Sjælland er, kan man sige, en Foregrihelse af Præsident Wilsons navnkundige 14 Punkter, og Erik af Pommern, hvem man har smædet som vor sletteste Konge, fortjener Pris og Ere for sit Initiativ.

Men trods den umistelige Værdi, som Vidnesbyrdene og Dommen 1421-1424 har for os Danske, fik de jo ingen reel Magt. De holstenske Grever erklærede nemlig deres Kejsers Domskendelse for en værdiløs "Lap Papir«. De appellerede til Næveretten, og de sejrede. Alt dette faar vi bare intet at vide om hos Hr. Reimer Hansen. "Schwamm drüber!"

S. 31 omtales det plattyske Sprogs Herredømme i Nordslesvig. "Stadsretterne i Slesvig, Flensborg, Aabenraa (blev) fra Latin oversat dertil; indtil Tønder og Aabenraa gjaldt det (Plattysk) som Retssprog, tildels alene, tildels ved Siden af Dansk «.

Denne Formulering maa kaldes overmaade prisværdig i Sammenligning med de aabenlyse Usandheder hos Dr. v. B o elitzog Ziegfeld, Hendiriock og v. Loesch, som vi siden skal komme til. Men den er dog langtfra fejlfri. Enhver Læser maa jo tro, at alle Sønderjyllands Stadsretter oprindelig var paa Latin og derfra gik direkte over til Plattysk. Men det er jo aldeles forkert. Flensborg Stadsret af 1284 var paa Dansk, med danske Tilføjelser 1295 og 1321. Haderslev 
Stadsret var ligeledes paa Dansk, 1292, og det flensborgske Knudsgildes Skraa fra omkring 1300 ligeledes. Naar disse fortiede Kendsgerninger kommer til, faar Billedet øjeblikkelig et helt andet Udseende end hos Reimer Hansen, for ikke at tale om de moderne Fabeldigtere.

S. 77 kommer atter en Udtalelse, der maa anerkendes. Forf. siger om Gennemførelsen af den kongelige Regering 1773: "Foreningen af Landsdelene under ét Herredømme var en Lykke for Hertugdømmet, især for Gottorps Omraade, hvis Herskere i de sidste Aarhundreder havde gjort lidet eller intet for Landets Vel «.

Nøjagtig det samme, blot endnu stærkere, siger E c k a r d t i "Alt-Kiel in Wort und Bild«, jfr. min Artikel i »Sønderj. Aarb.«, 1937, 213. Eckardt siger f. Ex. om den sidste Gottorper, at hans Regering "var vel nok den sørgeligste for det haardt prøvede Land «. Han hilser det kgl. danske Styre som en ny Tids Morgenrøde.

S. 84 læser vi ogsaa en prisværdig oprigtig Udtalelse om det slesvig-holstenske Løsen »Up ewig ungedeelt«. »Det gamle Ord fra 1460, "up ewig ungedeelt«, blev til Slagordet, som, forstaaeligt for alle, gradvis drog alle Krese $i$ Landet ind $i$ det politiske Liv. Ganske vist var Ordenes oprindelige Mening, at kun e e n Fyrste skulde herske over begge Lande, bleven krænket ved de talrige Delinger; men de blev nu genoptagne til Forsvar for de "tyske Hertugdømmer«".

S. 87 omtales Indførelsen af dansk Retssprog i Nordslesvig 1840. Men det forties her, at det var en Ge $n$ indførelse (det maa Læseren selv huske fra S. 31), og at den fuldstændige Fortrængelse af det danske Retssprog først var gennemført i 1833.

S. 94, ved Omtalen af Rejsningens Udbrud 1848, forties Beselers Ord: "Havde vi ikke opretholdt Legitimiteten, vilde vi efter 3 Dages Forløb have været landflygtige i Hamburg«. Man kan selvfølgelig ikke vente at se disse kompromitterende ord citeret; Vidnesbyrdet er kun af en kedelig Fejltagelse sluppet ud af $\mathrm{Hr}$. Sachs Mund i hans "Geschichte der Stadt Schleswig" S. 310. Men vi Danske har den Ret og Pligt at gentage det 
overfor enhver tysk Skildring af Tildragelserne i 48, for at man kan se, hvor udbredt den danske Statsloyalitet dengang var.

S. 99 forties Sammenstødet mellem Landstormen og SlesvigHolstenerne ved Brøns.

S. 106, ved Skildringen af det danske Tvangsherredømme efter 1851, gøres en utilsløret Indrømmelse: "I Sydslesvig og det frisiske Omraade forblev Tysken uantastet«.

S. 116 skildres Kampen ved Helgoland uden Tilsløring.

S. 120 omtales flygtig Feltmarskalk Manteuffels Stejlhed overfor Arveprins Frederik af Augustenborg. Men ellers siges der intet om det preussiske Styre i Overgangstiden efter 64, -- dette Styre, som J a n s e n - S a mwer i "Schleswig-Holsteins Befreiung« kalder værre end det danske: "Folket skreg op i Fortvivlelse«.

S. 130 og 134 havner Forf. i en temmelig tendensiøs Skildring af det preussiske Styres Velsignelser og den tyske Forenings Heltegerninger. "Skoleinstruxen af 1888 (er) en Fortsættelse af den i Aarhundreder foregaaede Udvikling henimod Tyskhedens Fremhersken. .... Nordslesvigs "Genopvaagnen" var kunstig, Tyskhedens Fremtrængen en naturlig sig fuldbyrdende Proces«. .... »Saaledes fandt den Tyske Forening, der holdt vaagent Øje med Agitationerne ("die Wühlereien "), Modsigelse ogsaa hos Tyskere, mere udenfor Nordmarken, hvis Tilstande i mange Aviser ikke blev paalidelig fremstillet, end i denne Landsdel selv«. Dr. Mackeprangs "Nordslesvig" affærdiges som "absolut ikke objektiv«. Hvorpaa Hr. Hansen dokumenterer sin egen Objektivitet ved at henvise til den monomane S trackerja $n$ ! Kommentar er overflødig.

Hermed forlader vi Reimer Hansen, hvis Fremstilling danner en underlig Blanding af Saglighed og Tendens.

1913 fornærmede Rektor R e t e r fra Lübeck dansk Videnskab ved paa et altysk Møde i Flensborg at sigte den for af politiske Grunde og mod bedre Vidende at annektere Sønderjyderne som danske. Krævet til Regnskab af mig, fremkom Rektoren med et yderst tyndt Forsvar i "Apenrader Tageblatt« 
9. Jan., se min Artikel "Prof. Reuters Forsvar for Annexionslæren" ("Nationaltidende" 28. Jan. 1914, Aft.). Han kører op med nogle forældede Udtalelser af Molbech og N. M. Petersen, og derefter citerer han den gamle Krønikeskrivers Ord om, at Kong Sven Estridsøn tilbageviste de til Sønderjylland udsendte hamburgske Gejstlige, fordi de var ukyndige $i$ »linguae patriae e t Danicae"; han oversætter det saaledes, at Hamborgerne "hverken forstod Landets Sprog eller Dansk «. Han tilføjer for at være morsom: "De kunde hverken "snakker eller "taler" (!)«. (Et smukt Vidnesbyrd om hans egen danske Sprogkundskab, naar han troer, Infinitiven ender paa r). Enhver, der kender til middelalderlig latinsk Stil, veed, at Rektorens Oversættelse af de latinske Ord er gal; Ordene "linguae patriae et Danicae« vil simpelthen sige »det fædrelandske danske Sprog«. - Da Rektoren hverken var til at hugge eller stikke $i$, henvendte jeg mig til mine tyske Fagfæller, og tolv af dem stadfrestede loyalt, at „om Vestjyskens Danskhed er der ingen Strid mellem tysk og dansk Videnskabu. (Sønderjysk regnes jo som en Afdeling af Vestjysk). Prof. Collitz fra Baltimore ledsagede sin Underskrift med en meget kraftig Dom over Rektorens Uforskammethed, citeret af mig i »Nationaltidende» 15. April Aften, "Dybbel-Posten" og "Dannevirke" 16. April. Hr. N is Schröder maatte i et tysk Blad med Sorg og Græmmelse erkende Annexionslærens knusende Nederlag.

1913-23 udgav Prof. Fr. Ka $\mathrm{u} f \mathrm{fm}$ an $\mathrm{n}$ i Kiel sin store etnologiske Haandbog "Deutsche Altertumskunder. Det er et uhyre lærd Værk, hvori man kan finde mange værdifulde Oplysninger. Den udmærkede østrigske Etnolog $\mathrm{Rudolf} \mathrm{M} \mathrm{u} \mathrm{ch}$ giver det imidlertid i »Zeitschr. f. deutsches Altertum« en haard Kritik. Og sikkert med Rette. Kauffmann hører til samme Type af den grundlæggende Etnolog Zeuss' Efterfølgere som Müllenhoff og Bremer, og Metoden kan nærmest kendemærkes ved Ordene "uden Hoved og Hale«. En broget Sammenhobning af Stof uden fast, overskuelig Plan, forskellig fra den Metodik, jeg har givet Prøve paa i min Haandbog "Vor Folkegruppe Gottjod«. Den tyske Etnologis Skødesynder frem- 
træder hos Kauffmann meget iøjnefaldende. I Bd. 1, S. 401 hedder det om Vestgermanerne: set afsluttet Sprogsamfund...., der er særlig godt afhjemlet ved vigtige og selvstændige sproghistoriske Oplevelser«. Her forsømmes enhver Opstilling af det for en Etnolog naturnødvendige Spørgsmaal: var dette Sprogfællesskab enstydigt med en udtrykkelig følt og udtalt Nationalitetsdannelse som den, vi i Vikingetiden finder hos Nordboernes "danske Tunge«? Med et saadant stiltiende "Schwamm drüber!" hopper Kauffmann over det kedelige Faktum, at en "vestgermansk Nationalitet" aldrig har existeret, som jeg har paavist i »Our Forefathers $\$ 1$ 147, jfr. Prof. Scheels Indrømmelse af min Paavisnings Rigtighed nedenfor S. 284. I det følgende tropper de udødelige "Vestgermaner" op utallige Gange som politisk Korporation i Modsætning til Nordgermanerne. - Indenfor "Vestgermanerne" drøftes I, \$ 68, den kimbriske Halvøs Indbyggere, og da Tacitus har kaldt Anglerne og deres Naboer for "Sveber", sees deri et nyt Vidnesbyrd om, at de tilhørte en ikkenordisk Nationalitet; Kauffmann overvejer slet ikke den nærliggende Mulighed, at Tacitus' "svebiske Grupke" kunde være en politisk Forstening fra Kong Marbods storsvebiske Rige 1-17 e. Kr., som deres Naboer Longobarderne paaviselig tilhørte. Forf. stedfæster nu de forskellige "Sveberstammer«: Haruder i Hardsyssel; Eudoser paa Als og Arø; smst. Suardoner og Nuithoner; Varner ved det af Müllenhoff opfundne "promuntorium Varinorum, nu »Warnitz«; Angler i Angel; Reudigner i Østholsten; Auioner paa Femern. Her har vi en Kærneprøve af den tyske Etnologis allerværste Slags: den kategoriske Stedfæstelse af en Række for Størstedelen helt ulokaliserbare Navne i Kraft af et professorisk "Vi alene vide«. Tydelig rigtige er kun to af Stedfæstelserne, Harudernes og Anglermes; Resten er løst Gætværk, der nu altsaa hældes paa de troende Læsere som "Videnskabens sidste Skrig". - I Bd. II umtales S. 181 Karl den Stores Underkuelse af Saxerne i Holsten. Ved denne Lejlighed siger Forf. ikke en Stavelse om Saxernes oprindelig ikketyske Nationalitet, der endnu røber sig i Stednavne som holstensk Zenhusen, hannoversk Celle etc. 
Denne Fortielse er normalt gennemført i tysk Literatur; men Bremer vedgaar jo dog i sin "Ethnographie« udtrykkelig Saxernes ikketyske Sprogpræg; da Kauffmann vil være Etnolog, er Fortielsen hos ham dobbelt forkastelig. - - S. 181 hedder det: "efterat nordgermanske Daner har opkastet sig til Herrer over Vestgermaner, er der opstaaet en jysk-dansk Folkestamme og tillige ved Blanding af Østnordisk og anglofrisisk Sprogbrug ved en "Lydforskydning" det danske Jysk nordfor Ejderen«. Vi seer her den kendte tyske fejlagtige Opereren med "Vestgermaner" og "Nordgermaner" som to hinanden fjendtlige Nationaliteter, - et fuldkomment Fantasibillede. Hvad Forf. mener med den mærkelige "Lydforskydning «, der skaber det dansk-jyske Særpræg, er mig gaadefuldt; her gør han nærmest Indtryk af at vrøvle. Derimod udtaler han sig S. 257 helt klart om Nordalbingerne: "De blandt dem brugelige Stednavne er meget forskellige fra Navnene i Slesvig, hvor Navnegivningen som Følge af Folkevandringen blev dansk«. Altsaa, Kauffmann samstemmer her fuldkommen med Eskildsen og med Svarene paa mit Rundspørge i 1937, hvorefter der i Stednavnepræget er en knivskarp Grænse mellem Sønderjylland og Holsten.

Des mere perplex blev man ved at høre, at Kauffmann selvsamme Aar, 1923, for en Forsamling af f́lensborgske Skolepiger forkyndte, at Jysk var wet ægte Kolonialsprog «, og at »den jyske Dialekt burde slet ikke kaldes dansk «. Iøvrigt diskede han op med den kendte tyske Jeremiade om dansk voldelig Erobring, Erobring, Erobring. Foredraget blev under Titlen "Deutsch oder Dänisch? « siden udgivet af Slesvig-Holstener-Forbundet. Det viste sig imidlertid ved nærmere Eftersyn, at i sit "autentiske« Referat havde Forf. som klog General strøget den kriminelle Sætning om Jyskens Ikkedanskhed. Han maatte senere af mig $t v i n g e s$ til at vedgaa, at den svarede til hans virkelige Mening. For forudsætningsløse Skolepiger var denne Visdom altsaa god nok; men for kritiske Sagkyndige, der forud kendte Kauffmanns stikmodsatte Udtalelse i "Altertumskunde«, skulde den helst hemmeligholdes! Skade kun, at denne fine Trafik blev afsløret! Jeg skrev en saglig Imødegaaelse, "Die Stellung 
des Jütischen«, som Prof. Wil h. B ra u n e med fuld Billigelse optog i "Beiträge zur Geschichte der deutschen Sprache und Literatur «, Bd. 48, S. 141. Kauffmann svarede undvigende i et slesv. holst. Blad; et videnskabeligt Gensvar i »Beiträge« har han aldrig givet. Angrebet var eklatant afslaaet.

Afstemnings- og Genforeningstiden bringer naturligvis en Syndflod af Literatur om Nationalitetsspørgsmaalet, som det er vanskeligt at overskue. Jeg maa nøjes med at gøre enkelte Greb ned i Posen. Som Helhed kan det siges, at den tyske Produktion har meget ringe Værd.

1919 udkom et Skrift paa Dansk og Tysk af Lektor ved Berlins Universitet $\mathrm{Joh}$. Neuhaus, „Det nordslesvigske Spørgsmaal i Belysning af de nyeste forhistoriske Undersøgeler«. Jeg opforer det her indenfor den $t y$ sk e Produktion, thi Neuhaus regner jeg for Renegat. Det samme gør den nordslesvigske Tyskerfører Pastor Joh. S ch midt i meget anerkendelsesvardige Ord, se Karl Alnor, "Joh. Schmidt-Vodder (1929), S. 99. Schmidt skriver: "Med Docenten for nordiske Sprog i Berlin, Neuhaus, bliver der vel intet Samarbejde. Han er en Ivrer mod sit eget Folk, det danske, og hvis han har Sandheder at sige sine egne og dertil ønsker Hjælpere, søger han dem bedst blandt sine Landsmænd. Efter de Indtryk, som jeg fik, synes det mig psykologisk umuligt at være med. Har andre Tyskere erklæret sig rede, bliver det deres Sag. Jeg er tilbojelig til at holde det for forkert«. Lektorens Fantasier bruges som Argumenter af Kar l A lnor 1919 og endnu i "Nor d mark-J uge n d« 15. Marts 1937, se nedenfor. Jeg skal ikke dvæle længe ved dem; de er ikke værd, at man spilder sin Tid derpaa. Til Prøve blot følgende fra "Modernes Dänisch« (1913): "Hvad Jyllands gamle Indbrggere gælder, saa tilhørte de utvivlsomt Vestgermanerne. Vidnesbyrdene herfor er følgende: 1. De gamle Landskabsnavne (se "Jütländische Texte«); 2. Indtræden af -borg istedenfor -b e rg, saasom Viborg = Wibiærghe, Flens- 
borg $=$ Flinsbjerg scm Sejerherrens Mærke; 3. Sproglige Ejendommeligheder, som ingen anden Slutning tillader, og som dog ikke alle kan være opstaaede i Middelalderen, f. Ex. det foranstillede Kendeord for Hankøn og Intetkøn, 1. Persons Stedord a, Verbalformer som $\mathrm{g}$ a w $\mathrm{n}, \mathrm{g} a ̊ \mathrm{l}$ (w) $\mathrm{n}=$ eng. g o n e, Bortfald af det udlydende -e (k. $\mathrm{m} \mathrm{m}=$ eng. c o $\mathrm{m} \mathrm{e})$. - 4. Dobbeltformer som Hedeby (dansk) og Slesvig (stedlig). 5. Den Mulighed, at de æIdre Jyder (Eutii) sammen med Saxerne erobrede England. 6. Den udanske Udvikling af Stednavnè: Limfjorden, modsat oldn. Limafjordr, Saxo: Lymicus sinus, jfr. Lemvig; Ejder, "Vanddør " eller "Ødør" = Agwjaduriz, Egidora (først meget sildig dansk Ejder); Sli ved Siden af Slæ etc.«. — Disse Udtalelser fortjener kun een Karakteristik: V a a s. Af samme Surdej er Skriftet fra 1919. Det er nok at navne, at blandt de gamle Arvefællesskaber mellem Jysk og Engelsk anfører Lektoren uden at blinke $\mathrm{m}$ de wons $=$ on c e!! Der er blot det gale ved dette Fund, at $m æ d e$ w o n s ligesaa fuldt bruges af $K j ø-$ benhavnere, altsaa $\mathrm{Hr}^{\mathrm{r}}$. Neuhaus erobrer med dette Argument hele Danmark for sine Vestgermaner. Jeg henviser til mine Artikler »Urjyske "Vestgermaner« og moderne Fantaster« ("Nord. Tidsskr. f. Filologi«, 1919) og »En moderne Fantast« (»Græensevagten« 1919, S. 96).

I 1919 var Advarslerne forsaavidt spildte, som Karl A 1nor i Artiklen "Das geschichtliche und nationale Recht in Nordschleswig“ (i det af Pastor Joh. S chmidt udg. Skrift "Der deutsche Weg zur Verständigung mit dem Norden«, $\mathbf{S}$. 37) med krum Hals slugte Neuhauses Vrøvl og brugte ham som Kronvidne mod Danskheden; det var forst senere, at Alnor blev kendt med Pastor Schmidts Advarsel, som han ikke turde fortie. - Han vender sig lejlighedsvis mod "Kolding Folkebiad«, der den \%. August har sagt, at saa langt som Historien gaar tilbage, har Sønderjylland været en Del af det danske Rige. Dette kalder han en "Geschichtsfälschung«. Her maa man jo sige, at "hver har Ret paa sin Maade«. Daterer man »Historiens Gry " fra de sporadiske Glim.t i Tacitus' "Germania» Aar 98 e. Kr. var Landet utvivlsomt ikke dengang en Del af et dansk 
Rige; men daterer man "Historien" fra den sammenhængende Overleverings Start, var det ligesaa sikkert en dansk Rigsdel fra første Færd. Skulde man ikke engang kumne blive enig om at udtrykke sig præcist, saa man slap for det Vejrmølle-Øxeskaft, der kommer til Udtryk i Alnors Ordskifte med Koldingbladet?

Om "Up-ewig-ungedeelt«-Overenskomsten 1460 siger Alnor S. 43, at Kongehyldingen paa Gottorp 1721 ikke var eu "Gennembrydning eller Ophævelse af denne Pagt«. Men derpaa følger nogle meget ænseværdige Indrømmelser til den danske Opfattelse: "Man maa imidlertid paa den anden Side komme den danske Opfattelse saa meget imøde, at man maa indrømme, at Ordene »up ewig ungedeelt« først i d. 19. Aarh. er trængt ind i Folkets Opfattelse. Ved deres Oprindelsestid har de kun været Udtryk for Standskrav .... Dertil kommer, at de slesv.holstenske Arbejdermasser, hos hvem Sansen for det historiske naturligvis ikke er saa uddannet som i det slesv. holst. Borgerskab og i alle Lag af det danske Folk, ogsaa $i$ den nuværende Kamp paa ingen Maade har kunnet blive varme for disse historiske Erindringer, ja, at de tværtimod ostentativt afslaar at gribe dertil .... Man kan .... være ked af dette, men maa politisk regne med en saadan Holdning, og derfor maa man ogsaa paa tysk Side til syvende og sidst opgive at løse det nordslesvigske Spørgsmaal paa Grundlag af et rent hitorisk Retskrav «.

1920 udsendte Joh. Tiedje »Die deutsche Note über Schleswig, mit einer Karte, 4 Tabellen und 2 Anlagen, im Auftrage des Auswärtigen Amtes herausgegeben ", med en Indledning af Statskommissær Dr. K ö s te r. Det er et Indlæg for det "geschichtlich geheiligte Panier des "up ewig ungedeelt««. Invrigt argumenteres der med akonomiske og andre saglige Grunde .Argumentationen løber ud i Forslaget om den saakaldte T i e d j e-L in je. I "Der Tiedje-Gürtel" vilde if. S. 17 være 6735 tyske Stemmer mod 5658 danske; i Tønder skulde der være 5540 tyske mod 3576 danske. Som ikke tilstrækkelig sagkyndig skal jeg undlade at komme ind paa disse Enkeltheder. At de ikke 
alle er lige vægtige, fremgaar vel af, at det tyske Flertal i Tønder 1937 forvandlede sig til et Mindretal.

Sagtens fra 1920 (uden Aarstal) stammer Rektor C. D. P etersens Skrift "Tondern, eine deutsche Stadt«. Her samles Vidnesbyrd til Gunst for Tyskheden, udgaaende fra den lybske Stadsret af anno 1243. Der sluttes med disse Ord: "Tønder, der aldrig havde viist dansk Sindelag, var med sine ægte slesv.holst. sindede Indbyggere atter en tysk By og saa fremdeles en Are $i$ at gælde som saadan". Vi skal nedenfor se, at Bỵen $i$ 1923 blev forfremmet til Frisernes Hovedstad, og at den "treudeutsche nordfrisiesche" Nationalitet i 1921 udstraktes helt nordpaa til Løgumkloster. Hvad der dog altsammen ikke forhindrede, at Tyskheden i Tønder blev Mindretal i 1937.

Sagtens fra 1920 (uden Aarstal) stammer ogsaa Digterpræsten Gustav Frenssens Skrift "Ein letztes Wort an die Nordschleswiger“. Af dette Skrift, der nærmest hører hen under Rubriken Digterlyrik, kan noteres følgende karakteristiske Udgydelser:

„0, skulde jeg vakle mellem disse to, mellem denne Brusen af et stort Folks urgamle Silkefaner med vidunderlig Historie og saa det falmede lille Dannebrog? "...... "Hvis Tønder og Flensborg bliver danske, da vil Tønder og Flensborg brænde! Om efter 5 eller efter 50 Aar, det veed jeg ikke, men jeg veed, at de vil brænde«. En frygtelig Spaadom, som Tønder endnu maa bæve under i 32 Aar! Iøvrigt er det nærmest komisk at se Hr. Frenssen nedsætte det lille falmede Dannebrog i Sammenligning med Tysklands "urgamle" Faner, da jo Dannebrog, som man veed, overgaar dem i $A$ Elde og har et individuelt Navn, som de savner.

1920, 1. Marts, udsendte den nye Republik Schlesw i g-H o ls te in et Opraab, hvori det hedder: "Slesvig-Holstenere! I Aarhundreder har Slesvig og Holsten levet sammen i inderligste og lykkeligt Fællesskab. Sammen blødte de paa talrige Slagmarker, sammen forsvarede de deres tyske Folkevæsen, deres Ejendommelighed og deres Rettigheder, sammen 
værgede de sig mod ethvert Forsøg paa at drage en Skillestreg mellem slesvig og Holsten «.

Dette illustrerede jeg ved i "Flensburger Norddeutsche Zeitung " 8. Marts at aftrykke de tysksindede nordslesvigske Embedsmænds Erklæring i "Schlesw.-holst. Zeitung" 20. Marts 1849, hvori Nordslesvigernes kærnedanske og antityske Sindelag dokumenteres paa alle mulige Punkter, se Allen, "Det danske Sprogs Hist. i Sdj.«, II, 481, og mit Skrift "Sønderjylland kalder «, S. 52.

1920 udgav Dr. Otto S c hüt en Afhandling, "Entwicklung der Schriftsprache im ehemaligen Amt und in der Stadt Flensburg bis 1650«, udførlig refereret i "Unser Schleswig " 27. Februar. Afhandlingen kaster interessante Strejflys over de Trællekaar, der i Reformationstiden bodes Danskheden i Flensborg. Se min Artikel "Die immerdeutsche Schriftsprache«.

Saaledes hedder det: "Det er grinagtigt ("ergötzlich") at læse, hvordan den eneste danske Præst, der selv kun skrev paa Nedertysk til Myndighederne, søgte at opbedre sin egen sociale Stilling som Fattigpræst, der stedse blev nævnt paa sidste Plads efter den tyske Hjælpepræest «.

Eller: "For at gøre en Ansøgning til Landsherren virksom, havde en Borger i 1577 ladet en dansk Advokat lave sig et Bønskrift paa Dansk. Men kun med Borgmesterens Tilladelse, og vel at mærke efter hans Diktat, vovede Advokaten det, efter at han forud udtrykkelig havde gjort Borgmesteren opmærksom paa, "at det ikke sømmede sig at sende danske Supplikationer fra denne Stad«. I et Raadsmøde blev da ogsaa virkelig Ansøgningens danske Form dadlet, og der blev forsket efter Sagens Omstændigheder «.

Altsaa allerede dengang Sindelagsspioneri! Vi mindes her Pastor Carstensens Ord i Visen om Modersmaalets Skæbne: "Længe nok har hun, tyske Frøken, blæret sig i mit Sæde, jeg gnavet Ben«.

1921 læser vi i det fanatiske Grænseflytterblad »D i e K ön i g s a u f $ø$ lgende karakteristiske Udgydelse under et Billede af Kirken i Kloster: "Flækken Lügumkloster og dens Om- 
egn indehaves af et trofasttysk Landsfolk af nordfrisisk Stamme«!!! Vi mindes her den gennemførte Indsmugling af nordfrisisk Sprog og Kultur i Hr. A. J. Lorenzens Bog »Unsere Heimat Nordschleswig fra 1912. Og Exemplet synes at danne Skole.

1923 udkom der en Artikel om Nordfrisland. Jeg fortier med Forsæt den lærde Forfatters Navn, da jeg ikke ønsker at blamere ham. Deri hedder det bl. a.: "Saa Iod da. Danmark det ogsaa rolig ske, at Nordsognene af Friserlandet trods deres overvældende Tilslutning til det tyske Folkelegeme blev løsrevne fra deres frisiske Stammefrænder og indlemmede $i$ den fremmede Stat. Til denne Grundkendsgerning i alt historisk Liv tør ogsaa. Indbyggerne af det sønderrevne tyske Nordfriserland holde sig .... Over det ved fremmed Vold og Uret sønderrevne Nordfriserland lyse Troskabens Stjærne!« .... „Den anden Vedtægt for Grænseafstemningen .... sønderskar det tyske Nordfrisland $i$ to Dele og udførte Snittet med fuld Hensigt saaledes, at der blev udøvet et Tryk paa Afstemningen $i$ anden Zone, der skulde foregaa en Maaned senere .... Den sværeste Kamp for Hævdelse af deres nationale Art vil ganske vist de fra deres Stammefrænder løsrevne Nordfriser selv føre.*)《

Man lægge Mærke til Tankegangen! Forf. har Ret i, at Friscrfolket ved Zonedelingen blev splittet i to Stykker. Men saa gaar han videre og siger uden at blinke, at ved Grænsedragningen kom det nordligste Stykke til Danmark. Da jeg udbad mig en nærmere Forklaring, svarede han: jo, Tønder! Altsaa 'Tønder, som blandt sine 5000 Indbyggere (1923) vel næppe husede et Par Snese frisisktalende, og som i 1937 fik dansk Flertal. Jeg spurgte derefter Forf., om han havde været syg eller momentant sindsforvirret? Han svarede arlig nok, at han ganske vist hellere havde seet de nævnte Sætninger uskrevne. -

*) Prof. E. M ülle r, Husum, skriver i "Jahrbuch des Nordfriesischen Vereins für Heimatkunde und Heimatliebe«, 1922, S. 1: "Naar pu ogsaa trods Afstemningsresultatet den nordligste Del af Nordfrisland er politisk skilt fra, saa bliver vi i Aanclen et med vore Brødre hinsides den nuværende Grænse i det faste Haah, at denne Adskillelse ikke kan blive varig«. 
Vi seer her, hvordan Fablen om det frisiske Nordslesvig stadig spøger rundt, 1912, 1921, 1923, og truer med at svulme op til helt fantastiske Former, naar den ikke prompte tages ved Vingebenet.

1922 "genudgaves« Pastor H. N. A. J e n s e n s udmarkede Værk fra 1844, "Angeln, zunächst für die Angler», ved Pastorerne IV. Martensen og J. Henningsen som "Angeln, geschichtlich und topographisch beschrieben von $H$. N. A. Jensen «. Men det er saa sandt ingen "Genudgave«. Det er et helt nyt Værk, spækket med løsrevne Stumper og Stykker af Jensen. Og Originalens Aand er stygt forvrænget. Den originale Jensen er loyal kongetro, taler om "unser Frederik", er venlig mod Landets gamle Danskhed, kritiserer meningsløse Fortyskninger som "Rundhof « for "Runntoft" osv.; hans Loyalitet fremgaar ydermere af et Privatbrev, som jeg har citeret $i$ min Anmeldelse i »Historisk Tidsskrift« 1925. Men Jensen af anno 1922 er ifølge Indledningen S. 8 en stiv Slesvig-Holstener, der "traadte i Skranken for sit Hjemlands bøjede Ret«; det danske Herredømme efter 1851 kaldes S. 291 et "Wilkürherrschaft«, stemples som »blindt fanatisk «; og den nye Jensen opvarter med Smædevers mod Danmark som "O, kleines Land, von Gott veracht't« og "Gott wolle uns behüten, dass wir nicht werden Jüten!« og med en Fortælling, hvor en Angelbo paa Plattysk siger til den danske Præst: "Hr. Pastor, De kan saamænd skære mig midt igennem, saa vil begge Ender dog skrige Slesvig-Holsten. Adjøs!« - Iøvrigt har jeg i min Anmeldelse nok dømt de to Præsters Værk lovlig strengt; det indeholder flere interessante Stykker, der kaster skarpt Ly's over holstenske Junkeres og den gottorpske Minister Kielmansegges sociale Hensynsløshed mod de indfødte danske Bønder og andre Smaafolk.

1923 kom Pastor Hor t man n s "Erinnerungen aus verlornem Land«. Deri findes en ondartet fordrejet Skildring af Landstormens Sammenstød med Slesvig-Holstenerne i Brøns 1849, bygget paa løs Sladder; jfr. Rigsarkivar L in val d s Artikel i "Festskrift til H. P. Hanssen«. Hr. Horstmann siger f. Ex., 
at de faldne Tyskere var: en Preusser og en Østriger. Han, der 5 Aar var Præst i Brøns, har altsaa ikke engang gidet læse den tyske Mindeindskrift paa Kirkegaarden, hvor der fortælles, at den ene var Sydslesviger, den anden Holstener.

1924 udgav Provinsialkonservator Ri ch. Ha u t $\gg D i e$ Bau- und Kunstdenkmäler der Provinz Schleswig-Holstein«, Bd. V. Heri læses S. 5 en interessant Udvikling om Byggeskikken som etnisk Skel:

"Ved Siden af Jyderne boer ogsaa Ødanskere, nemlig paa Halvøerne Angel og Sundeved samt paa Als. Afgrænsningen er endnu idag tilstrækkelig given ved den særegne Form for Mønningen paa deres Huse. Saaledes skiller f. Ex. Sognet Kværs sig skarpt fra det jyske Kliplev, og saaledes løber Linjen, uden at støtte sig til Naturgrænser, gennem de i sig selv ensdannede Landskaber. Det er meningsløst at paastaa, at denne Byggemaades tilsyneladende Ødselhed med Træ skulde forklares af en netop her forhaandenværende Overflod paa Træmateriale. Den er en Ejendommelighed hos det fra det germanske Nordostland indstrømmede Landsfolk, der sejgt er bleven fastholdt overfor Jyderne som en Slags Kendemærke paa højere Kultur. Til Ødanskerne har ogsaa Byen Slesvig mest holdt sig, og derved har den i Spændingstider skilt sig fra Jyderne. (Jfr. "Danm. R. Hist.«, I, 541, 636). Den dannede overhovedet en Indgangsdør for østlandske Indflydelser."

Disse Iagttagelser synes meget ænseværdige. Ganske vist bør det etniske Kriteriums Gyldighed ikke overdrives. Naar den ødanske Type siges at mangle i Kliplev, turde det være sekundært, thi Stednavnetypen -l e v turde jo netop være kommen til Jylland fra Øerne. Paa den anden Side fortjener Haupts Iagttagelser at bruges som Korrektiv til Prof. Scheels Teori, der nærmest kun vil anerkende det ødanske Elements Tilstedeværelse, hvor Typen -l e v forekommer. Thi i Angel savnes -l e v næsten fuldstændig, og dog har dette Landskab ifølge Haupt netop den ødanske Bygningstype.

1925 udkom Julius Tischendorf, "Das deutsche Reich, ein methodischer Beitrag zum erzieherischen Unter- 
richt«. S. 140 tales om Provinsen Slesvig-Holsten. Det hedder om Afstemningen 19:0: »Om en upartisk, retfærdig Afstemning kan .... der ikke vare Tale. Det maa smerte os, at Danmark, uden at have gjort et Svordslag, fik tildelt et Stykke tysk Land, der allerede paa Karl den Stores Tid hørte til Riget, senere ganske vist blev regeret af Kongen af Danmark, men aldrig skulde blive forenet med Danmark «. Vi møder her den fra Prof. Dahlmann stammende udødelige Fabel om, at Sønderjylland var et ty-sk Grænseland paa Karl den Stores Tid. Vi skal hilse paa den gentagne Gange igen. Naar Bogen kalder sig et metodisk Opdragelsesbidrag, maa vi sige: der er Metode i Galskaben.

1925 udkom den kielske Professor Otto Brandts "Geschichte Schleswig-Holsteins, ein Grundrissi. Den udgaves 1926 i dansk Oversættelse ved hans Hustru, f. Bartholin. Denne Oversættelse er en Tid bleven brugt som Læremiddel til danske Studenters Undervisning ved Kjøbenhavns Universitet. At den er meget fremragende, vidner Forf.s Ven, den udmærkede Forsker He demann-He espen i "Die Herzogt. Schleswig-Holstein und die Neuzeit", Fortale S. 10; han kalder Værket "denne Bog med vidunderlig indre Ligevægt og strængeste og modneste akademiske Læretugt«.

Ugunstig dømte derimod Arkivar Hjelholt $\mathrm{i}$ en Anmeldelse, der fremkaldte et vidtløftigt og fortørnet Indlæg fra Hedemann-Heespen. Jeg kan ikke andet end slutte mig til Hjelholt. At bruge Brandts Værk som Lærebog for danske Studenter er mildest talt mærkeligt, baade med Henblik paa, hvad den indeholder, og navnlig med Henblik paa, hvad den for ti e r.

Forf. starter S. 1 med den noget overraskende Oplysning, at "paa en vis Maade har der altidexisteretet"slesvig-holstensk spørgsmaal««. Hvordan, af hvem forfægtet, af hvem omtalt -, mon allerede i Noas Ark? -, det faar Læseren desværre ikke at vide. (Et Reklameskrift for Arkæologtidsskriftet "Offa « taler ganske vist om Slesvig-Holsteinisme allerede i Stenalderen!). Sætningen bliver staaende i sin sibyllinske Mystik, i Kraft af et professorisk "Vi alene vide«: 
Man kunde gøre gældende, at Forf. andensteds nærmest modsiger sig selv. S. 2 vedgaar han udtrykkelig, at der ikke fandtes nogen Kongeaagrænse. S. 5 hedder det om Slesvig: "Livligere end til Jylland gik Samkvemmet over til de danske Øer«. S. 9 omtales Offas Grænseværning mod sydlige Fjender, der ifølge den urgamle slesv.-holst. Idé jo egentlig skulde have været svorne Venner.

Iøvrigt noterer vi her den første alvorlige Lakune i Fremstillingen: om Saxernes $\mathrm{Nat}$ ionalitet ik ke en Stavels e. Nøjagtig som hos Kauffmann. Det forties altsaa, at de ikk e var Tyskere, men talte en engelsk Dialekt, om hvis Tilstedeværelse holstenske og nordhannoveranske Stednavne endnu minder, se ovenfor S. 258 Fortielsen er jo som sagt normal i tyske Skrifter.

S. 16 opgiver Forf. at forsvare den af Tyskerne tildels haardnakket forfægtede Lære om et i Aarhundreder, ja, Aartusinder existerende $t$ ys $\mathrm{k}$ Markgrevskab S lesvig; denne Lære er jo særlig gendreven af Steenstrup i »Danmarks Sydgrænse og Herredømmet over Holsten“ (1900). Dog er det tydelig en Mindelse om Læren, naar Forf. S. 47 hævder, at Sønderjylland faldt $i$ to Dele, hvoraf den ene svarede til det tidligere Markgrevskab. S. 22 siges: "For de næste to Aarhundreder (efter 1100) har Holsten og Slesvig, saa nøje og sa f r e m d eles deres Forbindelse blev, hver haft sin Historie: først i 14. Aarh. baner deres varige Forening sig Vej.« Hvori de tidligere »enge Beziehungen« ytrer sig, glemmer Forf. at sige; vi kan jævnføre $V$ ol q. P a u ls, i hvis Afsnit af 12. Aarh.s Historie i »Geschichte Schleswig-Holsteins« Slesvig mest kun glimrer ved sin Fraværelse; jfr. min Anmeldelse i »Grænsevagten«, Januar 1938.

Ved Omtalen af Erik af Pommerns Strid med de holstenske Grever forties, at Sønder- og Nørrejyder Aar 1421 vidnede om $S ø n d e r j y l l a n d s$ statslige, retsligeog sprogl ige Enhed med Danmark, og at denne "Folkets Røst« $i$ et statsligt Stridsspørgsmaal er noget nyt og uhørt i Verdens- 
historien, vel det første kendte »Plebiscit«. Det er overflødigt at tilføje, at Fortielsen gennemføres systematisk i tysk Literatur.

Ved Omtalen af Hertughyldingen 1460 f or t i e s, at det vidt udraabte "up ewig ungedeelt« var et ensidigt junkerlig t Stands l øs e n. Denne Indrømmelse gøres, omend sjælden, fra tysk Side. Saaledes af selveste Karl A l nor, se ovenfor S. 262. Endvidere skal jeg nedenfor citere $\mathrm{H}$ e d e m a $\mathrm{n} n$ H e s p e n $\mathbf{s}$ Ord om, hvordan man glemte, at der fandtes et andet Slesvig bag Junkernes - den danske Bondes og Haandværkers Slesvig.

S. 115, ved det gottorpske Holstens Overgang til kongeligt Eje, forties det gottorpske Vansty re, der saa malende skildres af $\mathrm{Eckardt} i$ "Alt-Kiel in Wort und Bild" og ogsaa indrømmes af $\mathrm{R}$ e i m er Hanse $\mathrm{n}$, se $\mathrm{S}$. 255.

At den haardhændede Fortyskning og Landsfolkets af mæg tige Protester forties, er en saadan Selvfølge, at det knap fortjener at nævnes. En redelig Tysker som H ed e mann-He es pen, der vedgaar den, er en hvid Ravn, se nedenfor S. 276. Jfr. Vidnesbyrdene i mit Skrift "Sønderjylland kalder«.

S. 136 tales om In $\mathbf{d}$ frelsen af dansk Retssprog i Nordslesvig 1840 . Det forties, at det var en Genindførelse, og at den fuldstændige Fortrængelse af det danske Retssprog først var opnaaet i 1833.

Fortiet bliver naturligvis Oprettelsen af Rødding Højskole 1844. S. 140 hedder det: „Og dog var Skriftdansken ligesaa lidt Modersmaalet som Højtysken,") selvom Skriftdansken allerede var fremherskende i Retslivet og i Kirke og Skole«. En skæv og uærlig Sammenstilling: mellem Skriftdansk og Jysk er der jo kun en Dialektforskel, medens Højtysk for Jyder som for Øboer er et vildt fremmed Sprog. Vilde man indføre Højtysk blandt Jyder, fordi det for dem ikke skulde være mere fremmed end Skriftdansk, saa kunde man med samme Ret indføre Skrift-

") I min Artikel i "Grænsevagten“ Juni 1938 staar ved en kedelig Trykfejl: »Højdansken«. 
dansk blandt Holstenerne, thi heller ikke for dem er Højtysken jo Modersmaalet.

S. 146, ved den slesv. holst. Rejsnings Udbrud forti e s naturligvis, at en af Førerne ifølge Ørevidnet Krügers Udsagn erklærede: Slesvig er tysk i Sprog og Sæder til Konge a a en. Forf. omtaler den provisoriske Regerings Kamp i L e gitimite tens og den "ufri Konges« Navn. Det forties naturligvis, at dette med den "ufri Konge" var Mundsvejr, H e d e m a n n-He e spen fastslaar udtrykkelig,o at Frederik VII hellere end gerne gik med Ejderdanskerne -, og at $\mathrm{B} \mathrm{e-}$ s e l e.r bagefter erklærede: "Havde vi ikke opretholdt Legitimiteten, vilde vi efter 3 Dages Forløb have været landflygtige i Hamburg" (S a c h, „Gesch. der Stadt Schleswig", 310).

S. 154 siges: "Naar der fra dansk Side atter og atter henpeges paa den preussiske Regerings Misgreb overfor Danskheden siden 1864, saa maa det fra tysk Side fremhæves, at de lang t f rakan s a m m en lignes med det System af stejle og ukloge Daniseringsforholdsregler, hvorved den danske Regering i de 13 Aar har gjort sig forhadt i Hertugdømmerne«. Dertil er kun at svare: Usandhed. Men at tvistes derom med den slesv. holst. Mentalitet turde være haabløst. (HedemannHeespen vedgaar Sandheden, se nedenfor). Imidlertid har Forf. aabenbart selv følt Usandheden, thi han vover $i$ den danske Udgave ikke at gentage Ordene $i$ deres fulde Skarphed; her hedder det kun, at de danske Tvangsforholdsregler i k k e s to d t il b a g e for de preussiske. Seer man det! Det var dog en væsentlig Forskel.

S. 160 hedder det om Ultimatum'et i 64: "I den Indbildning, at England, Frankrig og Rusland vilde hjælpe, har den danske Regering afslaaet det preussisk-østrigske Ultimatum«. Ogsaa Usandhed. De 48 Timers Frist var for kort til en forfatningsmæssig Imødekommelse af Ultimatum'et. Bismarck havde simpelthen med Flid gjort Imødekommelsen umulig.

S. 161 tales om "de i Dannevirkefortræf felig forskansede Danske« .... »de yderst stærkt udbygged e D y b bøl højder«. Aa, Herregud, at en Historiker vir- 
kelig gider diske op med dette Vrøvl om vore elendig forsømte Stillinger! Og naturligvis f or t i e s, at de Danske paa de "yderst stærkt udbyggede Dybbølhøjder sad værgeløse mod det langtrækkende preussiske Skyts!

I den følgende Overgangstid forties det preussiske Trangsstyrei Slesvig, - det, som faar JanssenS a mw er til i "Schleswig-Holsteins Befreiung" at sige, at Folket skreg op i Fortvivlelse, og som ogsaa He d e m a n n-H e espe n giver umiskendelige Exempler paa. Endvidere forti es Bismarcks Trick at sende Prins Hohenlohe til Nordslesvig for at udløse et dansk Smertensskrig mod Slesvig-Holstenerne. Endvidere forties Bismarcks kyniske Ord, at den Kylling, man selv har opdrættet, tør man dog nok dreje Halsen om paa.

S. 167 tales om Slesvig-Holstens "s t $æ r \mathrm{k}$ e Ops ving" under preussisk Styre. Det forties, at de nordslesvigske Byers Indbyggertal $i$ al den Tid stagnerede, medens samtidig de nørrejyske voxede stærkt. Enhver, der kommer til Nordslesvig, kan jo se, at Genforeningen med Danmark har været enstydig med, at denne Folketilvæxt nu ogsaa gør sig gældende her. Den døde Tid er forbi, og den døde Tid var - Preussertiden.

Jeg har opregnet en Række Punkter, der ved nøjere Gennemgang sikkert kunde oges med adskillige flere. - Men jeg har med Flid gemt det mest graverende af alle. Det kommer nu som Rosinen i Pølseenden i Kraft af min Bagvægtlov.

S. 15 læser vi, - jeg citerer her efter Oversættelsen -: "Den sørgelige Tilstand i Slesvig-Holsten hang igen paa det nøjeste sammen med den europæiske Tilstand i al Almindelighed, med Karolingerrigets Forfald .... Ingen Magt beskyttede i Tiden efter 860 de tiloversblevne Sachsere mod de røverske Normanners Indfald. Danmark var i Begyndelsen af det 9. Aarh. splittet, idet forskellige Smaakonger raadede paa Øerne og i Jylland. Men Gor m 'd en Ga m l e (860-ca. 940), e n y il d Tysker- og K ris t e n f or f ø l ger, som paa Sjælland havde sit sagnomspundne Kongesæde "Lejre«, skabte med Jærnhaand Rigsenheden«. (Derpaa følger nogle Ord om Gorms og Thyres Gravhøje). 
Hvad veed nu Hr. Professor ordinarius Otto Brandt fra det for sin Sandhedskærlighed navnkundige kielske Universitet om disse Ting?

Om Gorms Kristenforfølgelse veed han faktisk noget, eller kunde ialfald tro at vide noget. Thi Adam af Bremen, I, c. 48, brændemærker Gorm som en arg Kristenforfølger, der derfor har fortjent Smædenavnet Worm (Orm, Drage). Det har Adam sagtens hørt af Sven Estridsøn; det turde være Overdrivelse eller Opdigt, men det staar ialfald sort paa hvidt $i$ Kilden.

Men nu Gorms "vilde Tyskerforfølgelse«, - hvad veed Kilderne om den? I k k sa a meget $\mathrm{s}$ om bag pa a $\mathrm{n}$ Lillefingers $\mathrm{Neg} 1$ !! Og det er overhovedet $\mathrm{fantast}$ is $\mathrm{k}$ la $t$ t e r lig t at ville paadutte en Barbarstat som Datidens Danmark saadan en "Kulturblomst«, som en Nationalitetsforfølgelse maa siges at være. Ganske vist, kort før Gorms Tid rasede der nord for Elben en Nationalitets- og Trosforfølgelse efter alle Kunstens Regler. Den udgik bare ikke fra Barbarstaten Danmark; den udgik fra Kulturstaten Frankerriget og gik ud over det "slesvig-holstenske» Folk Saxeme, hvem Karl den Store massakrerede i 804 .

Naturligvis kommer Prof. Brandt i Fremstillingens Løb ogsaa til at tale om denne Tildragelse. Men mod Karl den Store er han mærkelig mild. "Saxerslagteren" slipper uhyre naadigt fra det. "Reden wir von etwas anderem«.

Og saa triner Prof. Brandt frem paa den dertil indrettede Estrade som en anden Professor Labri, svinger sin "historiske" Tryllestav, og - en-to-tre, hocus-jocus-pocus - er den fæle Saxerslagtning fra Karl den Store transporteret over paa Gorm den Gamle. Stakkels Gorm, der aldrig har krummet noget Haar paa Saxernes Hoveder, staar brændemærket som en "vild Tyskerforfølger«, udleveret til Efterslægtens Had og Foragt, som den "historiske" Foregangsmand for det hæslig kendte danske Voldsherredømme! "Sehen Sie, meine Herrschaften! Keine Hexerei, nur ein bischen Fingerfertigkeit«!« 
Og Publikum jubler. H e d e m a n n - H e e spen trykker Professoren Laurbærkransen om Panden: "wunderbares inneres Gleichgewicht..., strengste und reifste akademische Lehrzucht«. Universitetet $K \mathbf{j} ø \mathbf{b}$ enhavn optager det brandtske Produkt som Læremiddel for danske Studenter. Og Redaktør H a r b o e - K ardel lader "Nordschleswigsche Zeitung" 1935 udpille Fundet om "Tyskerforfølgeren Gorm" til Hjemmetyskernes Oplæring i Had mod den danske Voldsmagt. Ja, man skal høre meget, før Ørene gaar af een!

1926 udgav fhv. preussisk Statsminister Dr. O. v. B o el i tz "Grenz- und Auslandsdeutschtum«. Bogen, som findes paa Kgl. Bibliotek, er ganske af den brandtske Surdej. Afsnittet om Sønderjylland vrimler af de groveste Usandheder. Forf. paastaar ugenert, at Sønderjysk er "en Mundart, der intet har at gøre med det Dansk, der tales paa Øernew. Han fortæller, at der altid har hersket tysk Kultursprog i Nordslesvig. Højdepunktet naar han i denne Sætning: det er en "Kendsgerning, at Slesvigs Landsfolk gennem Aartusinder, (!!!!) har været tysk, af Hjærtet tysk" (!!!!). "Tatsache, dass die Bevölkerung Schleswigs Jahrtausende hindurch deutsch, bewusst deutsch gewesen ist«. I 2. Udg., 1930, har Forf. ganske vist strøget de værste af disse Usandheder, men uden at gøre Læseren opmærksom derpaa, saa at Ejerne af 1ste Udgave stadig maa sluge Kamelerne i god Tro. Jfr. min Artikel "Eine unrichtige deutsche Darstellung« (»Der Schleswiger«, 24. April 1937).

1926 udgav Godsejer Hedeman n - He es pe n sin tykke Bog "Die Herzogtümer Schleswig-Holstein und die Neuzeit«. Naar vi ovenfor har seet, at Forf. har ødslet en ufortjent Lovtale paa det brandtske Produkt, maa vi uvilkaarlig vente, at hans egen Frembringelse er af samme uheldige Art. Men dette slaar ikke til. Tværtimod. Hedemann-Heespens Forfatterskab cr afgjort Højdepunktet af, hvad Hertugdømmerne kan præstere af karakterfast Redelighed. Jeg maa regne det for en Lykke, at jeg i 1927 opsøgte denne udmærkede Historiker paa hans Borg og saaledes larte ham personlig at kende; desværre 
kendte jeg dengang endnu ikke hans her næunte Bog. Den indeholder en saadan Fylde af ypperlige Enkeltheder, at det er saare vanskeligt at gøre et passende Udvalg. Modsat Dr. v. Boelitz og andre Annexionister, der taler om Tyskhedens uafbrudte, sejrrige Fremrykning. fastslaar Forf. S. 333, 468 og andensteds, at Plattysken, hvis Sejr i 15.-17. Aarh, havde syntes saa fuldkommen, senere veg tilbage for et stærkt Fremstød af Jysken i Købstæderne. Hele dette Stykke danner et godt Supplement til Allens Sproghistorie. Tysk Sprogtvang og Protester derimod omtales oftere; S. 469 læser vi: "Men de fyrstelige Tjenestemænds Tarv var udslaggivende i hin Højblomstring af "Dannelsen" som en Selvfølge. Aldrig var man fjærnere fra en Brydning mellem forskellige Nationaliteter end i len uindskrænkede fyrstelige Centralstats Tegn«.

Om Folkenodsatuingen mellem Slesvig og Holsten hedder det S. 600: „En højere dansk Officer skrev (1813), ... da han med Tropperne havde Ejdergræensen bag sig: han var glad ved at have forladt et Land, hvori man ikke vidste at paaskønne Iærens Møje; ingen Deltagelse, snarere Ønsket om at være Danmark kvit; næppe var man i Slesvig, saa vedkender alle sig uden Sky at være danske og velsigner Vaabnene. Den holstenske Diplomat Rist havde ganske vist paa samme Tid det Indtryk, at i Nationalitet laa den danske Grænse ikke ved Ejderen, men ved Slien og Trene. Det var Gransen for Afstaaelsen i 1260 og $1288 \ll$.

Meget ænseværdige er Forf.s Ord i Anledning af, at Dahlmann i Ridder'skabets Adresse af 18. Okt. 1816 genfremdrog det gamle Løsen "up ewig ungedeelt» som Enhedsløsen for et tysk Slesvig-Holsten: "At der bag derved endnu kunde gives et andet Slesvig, Bonden, Haandværkeren, Smaakaarsmanden, regnede man i 1815 ikke med. Dette Folkevæsen var stumt, det havde ingen offentlig Mening. Man saa deri intet andet end det selvfølgelige Vedhæng til de "Dannede«. Først Paulsen har opdaget den nordslesvigske Bonde; forst en Menneskealder efter 1815 har denne selv meldt sig«. (Jfr. S. 635, hvor 
der tales om "en praktisk Rejsning af de nordslesvigske Bønder mod de indbildske Udbyttere og Retsfordrejere, som han i Aarhundreder kendte og hadede i de tyskdannede og tyskfødte Embedsmænd og deres indvandrede Vedhæng. »Det bliver først godt igen, naar der ikke mere er en eneste tysk Skrivepen i Landetu(u). - $\quad$ - Om den preussiske Sprogtvang efter 1888 hedder det S. 766: "Den danske Skoletvang fra 1851 blev overbudt«. S. 768 læser vi: "Samtidig med Opsvinget $\mathrm{i}$ den grundtvigske Danskhed omkring 1890 indledes i Tyskland, fremfor alt i Preussen, Nedstigningen til den fuldkomne Sjælløshed .... Assessorismen kommer".

Kun ugerne tager jeg Afsked med Hedemann-Heespen; men Pladsen tillader ikke flere Prøver af hans Bog, der er saadan en Fundgrube for overlegent humane Synsmaader.

1927 skrev E rich S ch laiki er i "Tägliche Rundschau", 22. Febr. ff., en lang Artike] om sin personlige Stilling til Nationalitetsspørgsmaalet. Han siger bl. a.: »Mellem en tungnem Vestjyde og en Ødansker er der en meget afgjort Forskel; alligevel er begge danske. Ligesaa er Holstenerne og Rhinlænderne meget forskellige, men alligevel begge tyske. Da Nordmændene var forenede med Danmark, antog de dansk Kultursprog og Nationalitet. Det t.jener dem efter min Mening ikke til Fre, at de nutildags arbejder paa Ødelaggelsen af dette skandinaviske Fællesskab. Naar altsaa nogen vilde sige, at Nordslesvigerne ikke kunde være danske, fordi der var Forskel mellem de nordslesvigske og den ødanske Stamme, saa var det i mine Øjne dumt. Naar paa den anden Side en Dansker vilde sige, at Slesvigeren ikke kunde være tysk, fordi han $f$. Ex. var forskellig fra Holsteneren, saa var det e $\mathrm{n} d \mathrm{n} u$ dummere, thi det overvejende Flertal af alle Slesvigere er nu engang tysk og hænger med Storms dybeste Inderlighed ved sin Tyskhed, medens den ranske Nationalitet er indskrænket til en Haandfuld danske Nordslesvigere«. I Hovedsagen har s. utvivlsomt Ret. Blot understreger han lovlig stærkt de danske Nordslesvigeres Faa. tal; jfr. ogsaa Sætningen: "Men Tallet var saa ringe, at det umulig kan forklare den tyskfjendtlige Monomani, hvortil Dan- 
mark i den følgende Tid henfaldt«. Vi skal siden se, at en Præst som Joh. Tonnesen udtaler sig med ganske anden Agtelse for Nordslesvigernes "lille Flok«.

1929 udgav $\mathrm{H}$ ill e n $\mathrm{Z}$ i e g f e ld, Heinz Hen d ri ock og K. v. Loes ch »Taschenbuch des Grenz- und Auslandsdeutschtums Heft 13, Nordschleswig“ (2. Oplag). Heri findes et Sprogkort, der ved mægtige Sprogøer gør det halve Nordslesvig tysk. Det hedder S. 6:

"Det omstridte Nordslesvig var, som hele Slesvig, i de første Aarhundreder e. Kr. Sæde for det vestgermanske Folk Anglerne .... Nord for dem sad Jyderne, der af en Rakke tyske Lærde (f. Ex. af den kielske Germanist Fr. Kauffmann) ligeledes regnes til Vestgermanerne.. En stor Del af de danske Forskere er ikke tilbøjelig til at indrømme Anglernes vestgerm. Præg, fordi derved den danske Ret til Slesvig "fra Arilds Tid“ falder bort. Derimod har netop Prof. Kauffmann i det lille Skrift "Deutsch oder Dänisch?" henpegeit paa, at Angler og Jyder ikke hører til det nordgermanske, men til det vestgermanske Samfund, altsaa ikke var Skandinaver, hvad forøvrigt ogsaa de angliske Kolonier i Nordthüringen stadfæster, hvor Stednavne som Eisleben og Aschersleben levende vækker Erindringen om Navnet Hadersleben«. - - Forf. har Ret i, at talrige eller rettere alle danske Forskere (paa nær Renegaten Neuhaus) nægter Jydernes og Anglernes "vestgermanske» Nationalitet. De anerkender nemlig overhovedet ikke Existensen af en "vestgermansk Nationalitet», efter at jeg $\mathbf{i}$ "Our Forefathers", $\$ 147$, har paavist, at denne "Nationalitet« er et tysk Fantasiprodukt. Nys har jo selveste Prof. O. S c h e el givet mig Ret heri, hvad vi siden kommer til.

S. 7 læser vi videre: "Fra da af $(1460)$.. har den tyske Kultur stedse holdt sig i Nordslesvig. Hvor der overhovedet fandtes Dannelse i Landet, var den tysk «. (Altsaa den store nordslesvigske Salmist Brorson var en Tysker og digtede sine Salmer paa Tysk!!). „Byernes gamle Dokumenter .. er stedse affattet paa Plattysk, senere paa Højtysk.. Dansk Kultur og rigsdansk Sprog havde deroverfor længe kun en underordnet 
Stilling, indtil det i 19. Aarhundrede ivrig blev bragt ind i Landet«. - Med Hensyn til dristige Usandheder kappes Forfatterne vardig med $\mathrm{Hr}$. Statsminister $\mathrm{O}$. v. Boelitz.

1929 starter Prof. Karl A l n or i Forbindelse med Prof. Carl Petersen, Prof. O. Scheel og Dr. Volquard Pauls en bindstærk "Handbuch zur schleswigschen Frage«, der skal danne en Modvagt mod Franz v. Jessens "Haandbog i det nordslesvigske Spørgsmaals Historie». Prof. Alnor har i Skriftet fra 1919 (se S. 262) givet enkelte Prover paa saglig Synsmaade, men i Skriftet "Schleswig-Holsteins Sendung und Erbe" (1935) viser han sig som en haardkogt Fanatiker, der jøvrigt af Argus har ladet sig stemple som en "løsmundet Sladderkælling« uden at sætte sig til Modværge. Hans Haandbog er en bundløs Samling af Avisudklip og andre sammenskrabede Notitser; jeg maa give Afkald paa at fordybe mig deri. Prof. Carl Petersen er vel sagtens en solid Forsker; Dr. Pauls har i sin Del af "Geschichte Schleswig-Holsteins" leveret et udmærket, sagligt Arbejde; men om hans Medvirken kan dæmme op for den alnorske Tendens, turde dcg være et Spørgsmaal.

1928 maatte jeg endnu slaas med et Ekko af Prof. Ge rl a n d s usandfærdige annexionistiske Sprogkort fra 1892, der optraadte i Mr. Bartholomews Atlanter. Det lykkedes endelig at faa Uvaesenet stoppet.

1929 fremkom i Konversationslexikonet Der grosse B r o c k h a us«, Bd. IV, S. 624-625, et Hustypekort, der indkasserer hele Sønderjylland for Saxerhuset. Jeg har paatalt denne Utilbørlighed i min Haandbog "Our Forefathers«, II, S. 308, og i et Brev til Redaktionen, som har lovet at sorge for en Rettelse i kommende Udgaver.

1930 udgav D i e c k e et "Schulatlas für höhere Lehranstalten«, der ligesom Gerland annekterede hele Sonderjylland som tysktalende. Da jeg paatalte det, sendte han mig Fortryk af et wrettet« Kort. Her var faktisk Nordslesvig erkendt som dansktalende, men med Rettelsen stod det kun daarlig til, thi fra Frøslev strækker sig en lang Udløber af tysk Sprog lige til Aabenraa, hvad der intet har med Virkelig- 
heden at gore. Hr. Diercke har her simpelthen tegnet Sprogkort efter Egnens ret udbredte tyske Sindelag. Det har man imidlertid ikke Lov til, naar Kortet kalder sig Sprogkort. - Helt andet Syn paa Sagerne har K n a u rs "Weltgeschichte« 1935, der for en Afvexlings Skyld fortysker det halve Vestslesvig, men lader Østkysten fri. De tre Kort passer til hinanden som en knyttet Næve til et blaat Øje. Jfr. min Artikel »Tysk Verdenshistorie og Sønderjylland" (Dagens Nyheder 11. Marts 1935).

1930 udgav Dr. P f e r d m e n ges et Skrift "Deutschlands Leben" (Forlag Deutsches Haus, Hamburg), se "Grænselandet«, 15. Sept. 1938, S. 7. Det er nys genudgivet med Forord af Dr. Hashagen, historisk Professor ved Hamburgs Universitet. Skriftet bringer et Kort "Deutschland um das Jahr 1«, der er et Non-plus-ultra af Umulighed. „Tyskland«, - hvis Navn først kendes 1000 Aar senere - ejer de romerske Rigslande Belgien, Rhinprovinsen og Helvetien med deres omtrent rent keltiske Indbyggere. Endvidere har "Tyskland« opslugt hele Jylland, hvad der ikke finder svageste Hjemmel i klassiske eller senere Kilder; det er kendt nok, at Hovedparten af Jylland politisk og nationalt aldrig har været tysk. Et Kort fra Aar 500 skænker Sønderjylland indtil Kongeaaen til Saxerne, :medens Resten af Jylland overlades de "tyske" Jyder. Det er forbausende, at en historisk Professor ikke undseer sig ved at borge for saadanne Opdigtninger.

1931 skrev Provinsialkonservator Dr. R i c h a r d H a u p t en Artikel "Aufgaben dem Verständigen und Willigen" $i$ Tidsskriftet "Die Heimat«, Nr. 1. Heri satiriserer han over sproglig slet dannede Kancellistils-Navne som Østrig-Ungarn. Han siger, at et Rigsborgernavn som "Østrig-Ungarer" er en Umulighed; iøvrigt overlader han til Læseren deraf at drage Slutninger $\mathrm{m} . \mathrm{H}$. t. et Navn som Slesvig-Holstenere. Meningen er ikke til at tage fejl af. Man undres blot over, hvordan en saadan Aabenhjertighed har forvildet sig ind i Slesvig-Holstener-Tidsskriftet "Die Heimat". Jfr. min Artikel "En tysk Sandhedsforkæmper" ("Flensb. Av.« 14. Jan. 1938). 
1934 udgav Carl Schütte og Otto Gaede en "Geschichtsbuch für die Jugend des Dritten Reichs«, forlagt af et pædagogisk Forlag. Det er unægtelig en ret mærkelig Pædagogik, der her udfoldes. Forf. disker op med saadanne Skrøner som, at Frankeren Karl (den Store) har indrettet Slesvig som Grænseprovins, og at de Danske altid siden har ligget paa Lur efter den, indtil det lykkedes dem at rane den ved VersaillesDiktatet. Mellem den tyske Hærs Storværker i 1864 nævnes bl. a. "Stormen paa Dannevirke« !!!! Hvorfor mon ikke ogsaa Erobringen af Kopenhagen, Grønland, Spitzbergen? Et Værk med den Slags Blomster kan man spare sig at diskutere. Jfr. "Tyske Kolbøtter med Sandheden« ("Hejmdal« 3. Aug. 1935).

1935 udgav Prof. K a r l A l n or sit Skrift "Schleswig-Holsteins Erbe und Sendung«. Det er udstyret med talrige lærd udseende Folke- og Kulturkort, men den etnologiske Fremstilling i de ældre Afsnit er ret dilettantisk.

S. 6 hedder det: "Slesvig-Holsten er Germanernes Urhjem«. Denne Brug af Navnet Schleswig-Holstein i Forbindelse med Urtiden er tendensiøs og vildledende. Dobbelnavnet $\mathrm{S}$. $\mathrm{H}$. er en Kancelliblomst fra 16.-17. Aarh., NB. ikke før, men e f t e r Kristus. Jfr. Prof. Rich. Haupts ubarmhjertige Nedsabling af den, ne Navnedannelse i "Die Heimat" 1931, No. I.

S. 11 hedder det: "Naar der derfor skal gives et alternativt Svar paa Spørgsmaalet, om Slesvig oprindelig var vestgermansk (tysk) eller nordgermansk (dansk) Bosættelse, saa kan det kun falde ud til Fordel for den tyske Urbosættelse». - Da Argus i „Hejmdal« 27. Marts 1936 ankede over disse Udtalelser, oplyste Prof. Alnor i "Nordschl. Zeitung" 15. April: "Hvis han (Argus) forstod Tysk, vilde han af min Konstaterings Form have sluttet, at jeg, - som jeg ogsaa andensteds har gjort det - , selv vrager Problemstillingen Vestgermansk-Nordisk for den slesvigske Oldtid som videnskabelig Problemstilling, og at jeg kun har taget Stilling til den under den Forudsætning, at der udfra Grænsekampens kendte politiske Standpunkter skulde kræves et "alternativt« Svar derpaa«. Dette Svar turde være en Rekord i orakelmæssig Dunkelhed. Ingen jæun tysk Læser vil 
kunne faa andet ud af Prof. Alnors Ord i Skriftet, end at Slesvig har tyske Urindbyggere, hvad der jo er det rene Vrøvl.

Iøvrigt udtaler Prof. Alnor S. 54: »15 Aar efter Nordslesvigs Indlemmelse i Danmark (blev) ogsaa fra hjemmedansk Side (Hjemmedanskere $=$ indfødte dansksindede Nordslesvigere) udtalt, hvad Karl Alnor allerede ved Offentliggørelsen af den danske Valutaordning i Febr. 1920 havde forudsagt: at det var den kjøbenhavnske Finanspolitiks Maal gennem det indfødte Landsfolks økonomiske Ruin at aabne Døren for den rigsdanske Tilvandring til Nordslesvig for ved den saaledes opnaaede Ødelæggelse af Nordslesvigs nationale og sociale Særpræg endelig at gennemføre den i Aarhundreder forgæves tilstræbte, fuldstændige indre Indlemmelse i Danmark«. - - I dette paa Pusten tagende Langpunktum tales der væsentlig om moderne Politik, som vi her ikke skal komme ind paa. Men to Ting fortjener dog at mærkes. Prof. Alnor opfinder en hidtil ukendt Menneskeart "Hjemmedanskere", som han finder det fornødent at definere. Da "Hjemmetyskere» vil sige "dansktalende Nordslesvigere med tysk Sindelag“, saa maatte "Hjemmedanskere" logisk defineres som: "tysktalende Nordslesvigere med dansk Sindelag", - en Menneskeart, der imidlertid kun existerer i Hr. Alnors Fantasi. Disse monstrøse "Hjemmedanskere" tager han nu til Vidne paa, at det danske Styre i Aarhundreder har søgt at udrydde Nordslesvigs folkelige og samfundsmæssige Særart. Vi kender jo nok saadanne Udryddelsesforsøg fra Preussernes Side; af Sammenhængen maa det da forstaas, at Danskernes Snigmordforseg har været endnu langt mere ondartede. For at faa dette nøjere oplyst krævede Argus i "Hejmdal" 9. Maj, at Prof. Alnor skulde opgive sine "hjemmedanske« Sandhedsvidner; kunde eller vilde han ikke det, maatte han stemples som en »løsmundet Sladderkælling«. Prof. Alnor foretrak at tie stille.

1935 bragte "Nordschleswigsche Zeitung" en Notits, som vel maa hidrøre fra Redaktøren $\mathrm{H}$ a r b o e $\mathrm{Ka}$ a d e l eller ialfald er offentliggjort under hans Ansvar. Notitsen bærer den noget folelsesfulde Overskrift »Hier spricht die Heimat«, og denne 
Hjemstavnshistorie fortæller da folgende: "Slesvig var i 9. Aarh. Skueplads for Omskiftelser, der atter afhang af det rlanske Nordens Skrobne. Danmarks Magt var ved 9. Aarh.s Gry meget splittet. Forskellige Smaakonger fandtes paa Øerne og i Jylland. Da har Gorm den Gamle, en Tysker- og Kristenforfølger, tilvejebragt den danske Rigsenhed. I Jellinge ved Vejle findes Gorms og hans Hustru Thyra Danebods Gravhøje. Over Kongeaaen trængte Gorm gennem den tætte Farrisskov erobrende sydpaa til Slien. De svage sidste Konger af Karolingeratten bød ham ingen Modstand «.

Jeg har i "Hejmdal « 23. 2. 37 stemplet denne Art "Historieskrivning " som vitterlig Usandhed, uden at Hr. Harboe Kardel har saa meget som fortrukket en Mine. Siden har jeg opdaget, at han er ret uskyldig: han har kun som kaldsmæssig Ignorant slugt Prof. Brandts Fabeldigtning af anno 1925. Men iøvrigt digter Hr. Harboe Kardel trolig videre paa egen Haand, eller kvæder Prof. Scheels Litanier.

1936, 17. December, en anden Prøve af Hr. Harboe Kardels Historieskrivning: "Den ældste Tid viser Slesvig som et Kærneland for de germanske Stammer. Senere møder vi paa slesvigsk Grund blandt andet svenske Vikinger, Saxer (??!), Angler, Friser og Jyder. .Af disse Stammer har der under fremadskridende folkelig Adskillelse udviklet sig den tyske og den danske Nationalitet. Paa intet Tidspunkt har Slesvig været rent tysk, men lige saa lidt nogensinde rent dansk «. Det maa have været pinligt at rykke ud med Tilstaaelsen: "aldrig rent tysk «, men det trøster jo, at der kan tilføjes: „aldrig rent dansk «. Og nu Vurderingen: det danske Fremstød mod Syd var et "Voldsfremstød" (ja, af "Tyskerforfølgeren Gorm«, ikke sandt?), det tyske var en "fredelig Indtrængen af Bonde- og Haandværkerkultur«. Endelig faar vi at vide: "I Nordslesvig. er Tyskheden ligefrem bleven den stærkeste Værner af slesvigsk Egenart«. Man skal høre meget, før Ørene gaar af een!

1937, 19. Jan.: "Vi har henvist til, at Danskerne plejer at indlede Historien først med det Øjeblik, da de som Erobrere satte Foden paa slesvigsk Jord «. (Ja vist, "Tyskerforfølgeren 
Gorm den Gamle«, etc.). „Vi har paavist, at Slesvig ikke er nogen gammel dansk Folkegrund, .... og at Slesvig heller ikke i den følgende Tid har været et sluttet dansk Bosættelsesomraade. Begge Folk har derfor samme Ret til Slesvig. Det er paa højeste Tid, at man fra dansk Side gør sig fri af sine Forestillinger og yder den tyske Slesvigskhed den Anerkendelse, hvorpaa den med Rette kan gøre Krav..... Trods langvarigt Herredømme har Danskerne ikke kunnet give Landet noget dansk Præg. De tyske Ydelser paa det kulturelle Livs Omraade overgaar mange Fold de danske, og den gensidige Fordeling af Styrken er saadan, at kun henved en Trediedel af det slesvigske Landsfolk er dansk«. (Javist, alle sønderjydske Stadsretter var jo tyske, det flensborgske Knudsgilde og dets Skraa ligeledes, Nordslesvigeren Brorson en stor tysk Digter, Højskolen i Rødding grundlagt af Tyskere, og meidens Kirkelivet i det danske Nordslesvig sygnede hen, blomstrede det yppig i det tyske Sydslesvig og i Holsten, takket være den kristne Frontkæmper Frenssens Indsats!).

Vi kommer nu til den Storm, der rejste sig ved Fremkomsten af Eskildsens »Grænselære«. Jeg er imidlertid ikke klar over Datoerne. Hvis jeg daterer noget af det følgende urigtig i Forhold til »Grænselæren« bedes man undskylde.

1936, Oktober, holdt Prof. O. S c h ael i Flensborg et Foredrag "Hvorfor og hvorlangt blev Slesvig dansk? « Det er udførlig refereret i »Flensb. Avis« 20. Oktober; jeg formoder, det er det samme, som Dr. Vilh. la Cour finder refereret paa Tysk under Titlen "Schleswig, ein deutsches Grenzland« (»Grænsevagten«, Febr. 1937, S. 57). Foredraget indledes med en Ironiseren over Udtrykket "dansk fra Arilds Tid«. Derpaa taler Professoren ret vidtloftig om det mislige ved mange Stednavneteorier, men gaar saa over til at fastslaa et meget vigtigt Punkt: "Dengang de gamle Stednavne blev grundlagt her i Landet, existerede der i det hele taget ikke noget tysk Sprog«. (Altsaa urtysk er Slesvig ialfald ikke). »Først i 1850 blev for 
forste Gang af en Osloer den Paastand rejst, at Danskerne ikke havde været de forste i Landet, at der oprindelig havde boet. germanske Stammer her, og at i en senere Tid Daner var brudt ind. For den videnskabelige Renheds Skyld vil jeg sige, at man ikke kan opretholde den Paastand, at vestgermanske Stammer skulde have boet her før Danskerne. Jeg har tidligere troet det, men det er et Misbrug af filologiske Forestillinger. Gudmund Schütte, hvem jeg anser for en alvorlig Forsker, der kan tjene ogsaa vor tyske Forskning, har Ret, naar han værger sig imod, at vi overfor den danske Tesis sætter den vestgermanske. Thi lder har aldrig existeret nogen vestgermansk Samhørsfølelse. Forestillingen "vestgermansk" er dannet af Sprogmænd, men kan ikke bruges her.» Jfr. de tilsvarende Udtalelser i Skriftet "Schleswig - urdänisches Land?" S. 13 og i "Geschichte Schleswig-Holsteins" II, 63. Prof. Scheel sigter her til min Dokumentation i "Our Forefathers« § 147. Hans Indrømmelse er af kapital Vigtighed; thi paa den "vestgermanske Nationalitet" har de tyske Annexionister levet højt snart i hundrede Aar. Det er en Hovedposition, der her er opgiven. Man maa prise Prof. Scheels Redelighed og Mandsmod, at han saa klart og tydeligt forkynder de nye Signaler.

Endvidere udtaler han, at Saxland oprindelig hørte med til Norden; først omkring 800 knyttedes det til Tyskland. Ogsaa et frisk og frit Syn paa Tingene.

Iøvrigt er der i Foredraget forskellige tvivlsomme eller svage Punkter. Prof. Scheel siger f. Ex.: "Indtil Folkevandringstiden har ingen Danskene været her. Widsith-Sagnet nævner Anglerne, men ikke Danskere«. Dette er en mildest talt vildledende Formulering. Kvadet "Widsith " nævner Danekongen Alewih som en Fyrste, der trods sin store Manddom ikke overstraalede Anglerkongen Offa. $\mathrm{H}$ v or Alewih havde sit Rige, siges der intet om, altsaa heller ikke om, hvorvidt det muligvis allerede omfattede en Dell af Østjylland.

Endvidere hedder det: ${ }^{\circ g}$ selv for Endelserne -t $r$ p, -s trup og -torp, der siges at være en særlig dansk Endelse, der slutter ved Ejleren, gælder det, at man ogsaa sydpaa fin- 
der denne Endelse. Dér er den bare blevet omdannet til for Exempel -d orf (Meldorf). I Westfalen findes en hel Række af disse Stednavne«. Dette er meget daarlig udtrykt, og det kan næppe være Referentens Skyld, thi nøjagtig den samme rent dilettantiske Fremstilling findes i Prof. Scheels Skrift "Schleswig - urdänisches Land?" Han forstaar ikke, at det slet ikke drejer sig om selve Endels en -torp, der utvivlsomt er kommen til Danmark fra Tyskland. Det, det drejer sig om, er Sprogudviklingen -t o r p___-tru p. Det afgørende her om, er Sprogudviklingen -t or p -t rup. Det afgørende her er, at Sønderjylland efter en Snor deltager i den normaldanske Overgang fra -t or p til -t r u p, som derimod savnes i Holsten. Altsaa Grænsen ved Ejderen er tilstede trods Prof. Scheels Nægtelse. At Overgangen fra -t o r p til -t r u p kommer igen i Westfalen, gæider til Vandsbæk, fordi Forbindelsesleddet Nordhannover-Holsten - mangler. De westfalske Trupformer er et yndet Motiv i det annexionistiske Litani. Naar Prof. Scheel har kunnet genfremdrage denne gamle Traver, viser det kun, at han ikke er tilstrækkelig skolet som Sprogmand. Men de Anker, der saaledes paa forskellige Punkter kan fremsættes mod hans Foredrag, er i Grunden ikke særlig svære. De opvejes langt af hans virkelig prisværdige Fordomsfrihed ved Spørgsmaalet om "Vestgermanerne» og om Saxernes Stilling.

Senere paa Aaret holdt Prof. S $\mathrm{ch}$ e e l et Foredrag om samme Emne paa Lyceet i EImshorn. Efter Referat i "Nordschleswigsche Zeitung" gengives Hovedindholdet i »Flensb. Avis« 14. Dec. 1936. Prof. Scheel understregede afsluttende: "Danskernes Kraft var ikke af den Art, at de havde kunnet udforme et saa stort Landskab (som Sønderjylland). Rigtignok kom dengang Danske ind i Landet, de er indvandret efter Vikingeskik og har bragt det til en 25 Bosættelser, hvis Navne for det meste ender paa "lev".

Danskheden udgjorde saaledes kun en helt lille Islæt $\mathrm{i}$ Sammensætningen af Slesvigs Landsfolk. Der kan aldeles ikke være Tale om noget urdansk Omraade. Danskheden er en svag Import udefra. 
Og selv om det er lykkedes Danskheden for kort Tid at hringe Landet $i$ sit politiske Herredømme, forải den daværende tyske Kejser, Konrad II, ikke svang sig op til nogen Interesse derfor, saa kom snart efter dog nye tyske Kræfter, del trængte ind i Omraadet og gjorde den tyske Indflydelse gældende. Saaledes har Slesvig aldrig og til ingen Tid været et rent dansk Land. Det har hverken urdansk Bosættelse, eller det er nogensinde lykkedes at give det et dansk Præg.

Slesvig er et Granseland, hvor det, der hylder det ene Folk, maa nyde samme Ret som det, der hylder det andet Folk «.

Her er Prof. Scheel stærkt paa Veje henimod et Standpunkt, der maa kaldes tendensiøs Vrangfremstilling.

Han taler om de 25 Levbygder i Sønderjylland som en "svag Islæt«. Det vil sige, han postulerer, at Landets Danskhed skulde opstaa ved mere eller mindre gennemført Kolonisation af de fra Øerne indvandrede Daner. Men det er jo et fuldstændig forkert Billede. Overført paa Tyskland vilde det sige, at man udpegede en enkelt Stamme som de "rigtige" Tyskere. Det maatte vel nærmest være de statsgrundlæggende Franker, og deres Stednavnetyper, f. Ex. -h e i m, skulde da være det Kriterium, hvorefter den ægte Tyskhed maaltes. Man vilde da komme til det Resultat, at Tyskheden i mange Egne af Tyskland kun var en "svag Islæt« eller helt manglede! Men saaledes skal det jo slet ikke sees. Danerne har samlet Danmark, ligesom Frankerne har samlet Tyskland. De ovrige Stammer har nationalt sluttet sig til Førerfolket, Sprog- og Kulturudviklingen har faaet fælles Retningslinjer. Det er det hele.

M. H. til den "svage Islæt" af Levbygder har Prof. Scheel sagtens i Foredraget allerede meddelt den Statistik, der foreligger i hans Skrift "Schleswig - urdänisches Land?«, hvoref ter der findes 91 -l e v paa nuværende svensk Grund, 137 paa Øerne, 104 i Nørrejylland, men „kun« 25 i Sønderjylland. Denne Statistik er imidlertid helt misvisende.

Nørre- og Sønderjylland stilles overfor hinanden som jævnvægtige Størrelser, medens Nørrejylland i Virkeligheden 
el ca. 3 Gange saa stort som Sønderjylland. Altsaa for at faa

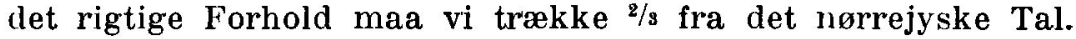
Istedenfor 107/25 faar vi da 35/25, - et himmelvidt forskelligt Forhold. Og i Landskabet Hardsyssel (Ringkøbing Amt), der er halvt saa stort som Sønderjylland, findes kun 2 Levbygder, siger og skriver to. Herefter skulde Hardsysselboerne være sex Gange mindre danske end Sønderjyderne. Enhver kan se, at den scheelske "Statistik " forer til den rene Absurditet. Endvidere er det iøjnefaldende urimeligt, naar Scheel paastaar, at Levbosættelser i Sønderjylland er en Kolonisation, der ebber ud med aftagende Kraft. Jeg har ved mit Kort i Bogen "Dansk Tunge« S. 41 godtgjort, at Sonderjylland er det eneste Sted paa den jyske Halvø, hvor Levbosættelsen for Alvor træenger igennem til Vestkysten.

Endelig maa vi lægge Mærke til den Paastand, at Sønderjylland fra første Færd er et tysk-dansk Blandingsland, hvor enhver af de to Nationaliteter har samme Ret. Det vil af Skriftet "Schleswig - urdänisches Land? " sees, at Prof. Scheel daterer Levbygderne i Sønderjylland til 6. Aarhundrede. Altsaa har Danskheden haft ca. 300 Aar til at virke, fra ca 500 og indtil ca. 800, da Kong Gøtrik byggede Grænsevolden Kurvirke, eller til 811, da Grænsen mod Frankerriget fastsattes ved Ejderen. Men ved Aar 800 var ikke engang Holsten tysk, langt mindre da Sønderjylland. Holsten matte Aar 804 ved Tvang vindes for Tyskheden. Først maatte altsaa de holstenske Saxer fortyskes, før Tyskheden kunde tænke paa at gøre sig galdende i Sønderjylland. Danskheden har paaviselig mere end 300 Aars Forspring. Det kommer man ikke udenom ved nogetsomhelst Krumspring, og det er det, vi Danske forstaar ved vor Førstefødselsret i Sønderjylland i Forhold til Tyskheden.

1937 udtalte Prof. S c h e e l paa Møder i Aabenraa og Sønderborg 11.-12. Jan., ifølge "Nordschlesw. Zeitung« 13. Jan.: "Der gives intet Tidspunkt, paa hvilket man kan sige, at Slesvig udgjorde en sluttet dansk Folkegrund. Det er den Virkeliglied, som Historien viser. I Slesvig er siden Vikingetiden to Folkeslag traadt frem overfor hinanden. I Jỵlland er Enheden 
med det danske Folk naaet, i Slesvig ikke. Slesvig er ikke gammel dansk Folkegrund, og i Aarhundredernes Løb har Tyskheden vist sig som den starkeste Folkelighed i Slesvig".

I 1936 udkom det a non yme Skrift »Aber Herr Eskildsen!« udgivet af Slesvig-Holstener-Forbundet og fremkaldt af Eskildsens "Grænselære«. Det er karakteristisk for Slesvig. Holstenerne, at deres Kæmper i vid Udstrækning ynder at "dølge Aasyn og Navn«; til de kendte Anonymer hører bl. a. A s mus von der Heyde*); Forf. til "Schleswig und Versailles«, og (oprindelig) Forf. til "Schleswig - urdänisches Land? « Hvem Forf. til Modskriftet mod Eskildsen er, kan der kun gættes paa. Han citerer gentagne Gange Hjemstavnsforskeren G ustav Fr. M e yer i Kiel og viser sig i Folkemindeforskningen ligesaa vel underrettet som denne. ${ }^{*}$ ) Men der er dog den Forskel, at det af G. F. Meyer udgivne Tidsskrift "Die Heimat" iagttager en sømmelig Tone, medens dette er det sidste, man kan sige om Anonymens Skrift. Den tapre Herre spiller overfor Eskildsen fra første til sidste Side paa Ledemotivet "Ach, er lügt ja!« Og hall citerer sjofle hjemmetyske Smædevers mod Danskheden som:

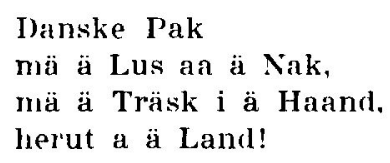

M. H. t. Sønderjyllands Stilling vil vi se, at han "misforstaar" Prof. Scheel langt ud over det tilladelige, eller ogsaa med Flid skærper hans Tendens. Vi hørte ovenfor, at Prof. Scheel i Elmshorn sagde, at wdet lykkedes Danskheden for k or t T i d at bringe Landet i sit politiske Herredømme«.

Det genfindes hos Anonymen saaledes formuleret: "Ingen tysk Folkeforsker vil nægte, at der for biga a end $e^{* *}$ ) har været en dansk Bosættelse indtil Slien«.

*) Nylig navngiven som Lærer J ü r g e n s e n.

* ) Alexander Thomsen siger i en neilenfor omtalt Artikel: "Schliesslich konnte Gust. Fr. Me yer die volkskundlichen Behauptungen der dänischen Grenzlehre zurückweisen«. Hvor er det skeet? Mon ikke netop i det anonyme Skrift?

${ }^{* *}$ ) Fremhavet af G. S-e. 
Altsaa Daniseringen fremstilles som noget, der kommer og svinder uden at efterlade sig dybere Spor. Og derpaa følger en tydelig fra Scheel laant Sætning: "Slesvig til Kongeaaen (er) et nationalt Blandingsomraade, hvori Tyske og Danske, ogsaa udfra Folkepræget ("volkskundlich»), har samme Ret«.

Sætningen illustreres nu ved Enkeltkritik af Eskildsens Bog, hvorpaa jeg her ikke skal indlade mig; det vilde føre for vidt. Derimod skal jeg, da Anonymen aabenbart staar Gustav Fr. Meyer ret nær, henvise til en af mig foretagen Gennemgang af denne Forskers Hjemstavnsskrift »Die Heimat«. Dette Tidsskrift kalder sig jo "slesvig-holstensk«. Men Faktum er, at det fra første Færd, og ikke mindst under Gust. Fr. Meyers Redaktion, fuldstændig forsømmer Nordslesvig til Fordel for sydslesvigske, frisiske og holstenske Egne. Undertiden er Nordslesvigs Repræsentering nærmest parodisk, som naar f. Ex. i Aarg. 1937 omtrent det eneste ænseværdige Bidrag fra Nordslesvig er en Skildring af den preussiske Fæstningslinje tværs over Landet! Hvis Landet op til Kongeaaen havde været saa gennemtræengt med tysk Kultur, som Anonymen siger, havde det vel kunnet levere flere Bidrag, og man havde ikke haft nodigt at forfalske Landskabsbilledet ved Indsmugling af frisisk Stof, saaledes som A. J. Lorenzen gjorde i "Unsere Heimat Nordschleswig 1912. Jfr. iøvrigt Eskildsens Modkritik "Schleswigs Boden und Volkstum«, 1938.

I 1936 skrev Dr. Lu dwig A n dresen imod Eskildsen "Von Volkstum und Namengebung im Schleswigschen". Dette Skrift, der i Modsætning til den fornevnte Anonyms er holdt $\mathbf{i}$ en sømmelig Tone, søger at vise, at Familienavnene paa $-\mathrm{s}$ e $\mathbf{n}$ i Sønderjylland aldeles ikke er noget typisk dansk. Det er jo kendt nok, at man kan finde Sen-Navne mange Steder sondenfor Danmarks Grænser, bl. a. ogsaa spredt rundt i Tyskland. Fra Holland kendes Jansen, efter hvem Sekten Jallsenisterne har faaet Navn. En kendt fandenivoldsk Altysker var Prof. Adolf Lasson; han var ganske vist ikke helt arisk ren i Kanterne, da han var fodt Lazarussohn. Overhovedet er Endelsen -s o h n hyppig blandt tyske Jøder, jfr. Kompo- 
nisten Mendelsohı. Særlig lægger Dr. Andresen Vægt paa holstenske Dokumenter mellem 1300 og 1500, der indeholder Former som Herberdessone, Everdessone, Boldessone, Eldeghessone osv. Men om disse kan man kun sige: de viser, at man $l$ visse juridiske Tilfælde har fundet det formaalstjenligt at kendemærke Mænd som deres Fædres Sønner, og at altsaa forsaavidt Forudsætningen for Opkomsten af et Familienavn paa -s e n har varet tilstede. Men denne Udvikling er faktisk udebleven; der foreligger kun et ufuldbaarent Foster. Og dette Fosters Tilstedevær kan ikke omstøde den af Eskildsen paaviste Kendsgerning, at der i Familienavnene er en knivskarp Grænse mellem Sønderjylland og Holsten. Jfr. Eskildsens Gensvar "Schleswigs Boden und Volkstum«, 1938, Kapitel D, samt min Artikel "Der Name Petersen" („Der Schleswiger", 4. April 1937).

1937, 17. Februar, offentliggjorde A lex a n d er Thomsen en Artikel "Wo bleibt die Schlei-Dannewirke-Grenze?", ligeledes rettet mod Eskildsen; den stod vist i "Schleswiger Nachrichten«. Artiklen sysselsætter sig med Haarfarve, Øjenfarve og Blodsfordeling og ledsages af tre Oversigtskort over Sydslesvig og Holsten; paa disse sees Svans og delvis det sydlige Angel at slutte sig til det holstenske Omraade. Forf. erklærer iøvrigt tilslut: "Vi anerkender uden videre Danskernes Ligeret i Slesvig. Vore Kulturer er i Slægt og vi er lig ea rtede ("artgleich"). Men deraf folger ogsaa en gensidig Agtelse og en gensidig Ridderlighed«. (Disse Ord kunde (len førnævnte Anonym passende have skrevet sig bag Øret).

Længere hen paa Aaret bragte "Nordschlesw. Zeitung" en Artikel af H. K., "Bedeutende deutsche Schleswiger«. Jeg henviser til den, da den kan bruges til Udfyldning af den ganske vist ikke udtømmende Liste, jeg har givet i mit 1937 udkomne Skrift »Das südjütische Dänentum«.

Ud paa Foraaret 1937 fremkom Skriftet "Schleswig - urdänisches Land?«, udgivet af Sleswig-Holstener-Forbundet; efter pængs sl. holst. Uskik var det anonymt, men Prof. O. S c he el har senere vertkendt sig Forfatterskabet, - hvorfor da disse 
Udgiver-Fixfaxerier? Skriftet er rettet mod Eskildsen; det indeholder ligesom Foredraget i 1936 forskellige tiltalende Enkeltheder. S. 73 citerer Forf. efter mit Exempel det gamle islandske Kildested om vort Folkegruppenavn Godthjod, Gottbjod (= Germaner), - et Kildested, der af de Lærde ellers haardnakket ignoreres; herom mere nedenfor S. 293. Endvidere gentager han S. 13 sin 1936 gjorte Indrømmelse, at "Vestgermanerne" som politisk Nationalitet er en imaginær Størrelse. Han hævder S. 35, at de mellemtyske Lebenbygder stammer fra forsvunden dansk Kolonisation; altsaa opgiver han Hr. Seelm a n n s Fantasi fra 1886, at Lev-Lebenbygderne skulde stamme fra Varnerne, - denne Fabel, der endnu til idag spøger i tyske Agitationsskrifter.

Men iøvrigt maa jeg stemple skriftet som forfejlet.

Om den misvisende Levstatistik (S. 30, 43) har jeg allerede talt ovenfor.

Ligeledes om den dilettantiske Paastand (S. 54), at der ved Overgangen fra -tor $\mathrm{p}$ til -tru $\mathrm{p}$ ikke lader sig iagttage en Grænse ved Ejderen.

S. 75 siger Forf.: „Dansk Folkegrund, som Øerne var det, og som Jylland blev det, blev Slesvig ikke«. Denne Udtalelse har jeg uvilkaarlig sammenstillet med hans Paastand i Elmshornforedraget, at Slesvig fra første Ford var et Blandingsland, hvor den ene Nationalitet ikke havde mere Ret end den anden. I »Der Schleswig-Holsteiner« 1937, S. 196, kalder Prof. Scheel dette en Mistydning. Han har - selvfølgelig - kun villet sige, at der indenfor Slesvig fandtes et Omraade med frisiske Indbyggere. Meget vel! Men hvad skal man saa sige om den Formulering, som den anonyme Forf. til "Aber, Herr Eskildsen!« giver Forf.s Ord (se ovenfor S. 288), eller om Friherre v. T ürckes Læsemaade i »Deutsche Arbeit«, August 1937: "Der har aldrig været en sluttet dansk Folkegrund i Slesvig. Hvad der lykkedes Danskerne i Jylland, at danisere hele Omraadet, blev dem nægtet i Nordslesvig«. Her er det saa tydelig som muligt sagt, at der aldeles ikke tænkes paa et frisisk Undtagelsesomraade. Nej, Nordslesvig tales der om; det er 
dette Land, der aldrig er blevet daniseret! Altsaa seer vi, hvad der kommer ud af Prof. Scheels uklare, misvisende Formuleringer. Jfr. min Artikel "Missdeutungen" i "Der Schleswiger «, Januar 1938, S. 13.

Ligesaa taaget og uklart udtaler han sig om Stednavnepræget. Hans hele Fremstilling deraf er uden Hoved og Hale, "words, words, words«! Og til min Kritik i Avis- og Tidsskriftartikler tav han haardnakket stille. Derfor saa jeg tilsidst ingen anden Udvej end at forelægge kyndige Sprogkendere følgende Rundspørge:

1. Er der nogen nævneværdig Forskel paa Stednavnepræget i Nørre- og Søndelijylland?

2. Kan Sønderjylland med Hensyn til Stednavne kaldes et Blandingsomraade? (Her sees bort fra Nordfrisland og det tyske Kolonisationsomraade mod Syd).

3. Findes der i sønderjyske Stednavne nogetsomhelst paaviseligt Spor af en »førdansk« Urgrund, d. v. s. et Stednavnepræg, som maa kaldes uforeneligt med det ellers i Danmark herskende?

Rundspørget indbragte et fuldkommen ensartet Materiale af Svar. Ikke et eneste Svar var til Fordel for den tyske Annexionisme. Jeg fremhæver særlig Svaret fra den udmærkede Anglist Prof. Th. Si ebs i Breslau, der allerede i 1911 havde tilbagevist de "vestgermanske« Annexionsfabler: "Fra tidligere Tid mindes jeg godt, at jeg gærne traadte i Skranken for Deres Domme om den jyske Dialekt; og jeg mener ogsaa nu ikke, at der mellem Slesvigs Stednavne - bortset fra nordfrisiske eller tyske Navne i Sydslesvig - findes saadanne, som er uforenelige med de i Danmark forekommende«.

Dette for Annexionismen temmelig tilintetgørende Resultat af Rundspørget tvang endelig Prof. S cheel frem. I "Der Schleswig Holsteiner" 1937, S. 196, kalder han nok mine Spørgsmaal for "Vexierfragen" og "Finten", men fremkommer saa med en meget utvetydig Erklæring: "Aldrig har jeg nægtet, at det stivnede, altsaa til Ro komne, færdige Stednavnekort i Sles- 
vig har dansk Præg. Jeg har endog viet det slesvigske Stednavnekorts danske Præg et eget Afsnit."

Hvortil da saa megen Udenomssnak? Havde han sagt dette strax, vilde megen Mistydning kunne have været sparet. Se iøvrigt min udførlige Anmeldelse i "Sønderjydsk Maanedsskrift«, Oktober 193\%, og mit Svar "Missdeutungen« (»Der Schleswiger«, Januar 1938), "Sprechendes Schweigen« (smst. Juli) samt Eskildsen, "Schleswigs Boden und Volkstum«, 1938.

1937 udgav Dr. W ill i W al te r P u ls, Lærer ved Højskolen for Læreruddannelse i Elbing, Skriftet "Nordschleswig, der abgetrennte Teil der Nordmark«, i Serien "Neuland in der Deutschen Schule, Beiträge zur praktischen Volksschularbeit«. Skriftet giver en helt igennem fordrejet Fremstilling af Nationalitetsforholdene og den nationale Historie. Det disker op med aabenlyse Usandheder, som at Stadsretterne i Slesvig, Flensborg, Aabenraa og Haderslev fra første Færd optegnedes paa Plattysk. Prof. Scheels i Forvejen temmelig taagede og misforstaaelige Udtalelser bliver fuldkommen forvrængede. Saaledes f. Ex. i Satningen S. 21: "Navne paa rup, trup, strup er opstaaede af Bygdnavne paa thorp, som vi ogsaa hyppig finder dem i Holsten, Hannover og Vestfalen.»

Heraf kan den forudsætningsløse Læser kun slutte, at Overgangen fra -t orp til - $t r u p$ er en speciel tysk Udvikling. Sammesteds hedder det: "At der maa have været en førdansk Bosættelse, viser ogsaa Stednavnene«, hvorpaa med Henvisning til Prof. Scheel nævnes Endelser som -ing og -s te d t; vi faar altsaa her serveret den Paastand, hvis Urigtighed Prof. Siebs har karakteriseret: at der findes et udansk Steduavnelag, uforeneligt med almendansk Præg. - Længere skal jeg ikke opholde mig ved dette Makværk; se Anmeldelsen i "Flensb. Avis" August 1937 og min Artikel i »Der Schleswiger«, Decbr. 1937.

I 1938 er Prof. S c h e e l endelig naaet til at udgive første Hæfte af $\sin$ Del af "Geschichte Schleswig-Holsteins«. Heri 
drøfter han bl. a. udførlig Spørgsmaalet om vort gamle nordiske Folkegruppenavn. Det vedkommer ikke meget SlesvigHolsten, men det giver ham Lejlighed til at vise prisværdig Uhildethed. Han fremdrager efter mit Forbillede det gamle islandske Kildested, hvorefter Folkegruppen hed Gctthjód, og han nævner Formen Gottoner, som jeg har indfort for at erstatte det tvetydige Folkegruppenavn Goter, og som han regner for et Navneforslag, der kan tages under Overvejelse. Han godkender ogsaa mit Rasonnement, at en Dobbelthed, GottjodGermaner, ikke er mindre rimelig end den almindelig anerkendte Dobbelthed ved Folkegrupper som Grsekere-Hellener og Vælske-Romaner. Det er jo kun ret faa Forskere, f. Ex. Otto Jespersen og Sigfus Blöndal, der hidtil har været tilgængelige for mine Paavisninger. Saa meget des mere maa det paaskonnes, at jeg finder Tilslutning i Tyskland, hvor jeg sidst havde ventet det.

S. 66 ff. kommer Prof. Scheel saa ind paa Stridsspørgsmaalet om Kimbrernes Hjemstavn. Vi har efterhaanden vænnet os til at regne det for afgjort og til at tage Kimbrernes Identitet med Himmerboer for en Kendsgerning. Saaledes ogsaa tyske Forskere som Marcks, Ih m og Rud. M u ch. Men nu skal Sagen altsaa paany drøftes. Ved Undersøgelsen har uden Tvivl ofte lokalpatriotiske Hensyn gjort sig gældende. Himmerlandsk Lokalpatriotisme er det, naar Aalborg Spritfabrikker lader Himmerlands-Billedhuggeren Bundgaard rejse den kimbriske Tyr et Mindesmærke og Himmerlandsdigteren Joh. V. Jensen digte Kvadet til dens Ere. Anti-himmerlandsk Lokalfjendskab er det, naar Vendelboen cand. mag. Jensen paastaar, at Kimbrerne og Kimbrertyren intet har med Himmerland at gøre. Og nu kommer Slesvigeren Prof. Scheel. Han holder først Foredrag om Kimbrerne ved en Hjemstavnsfest $i$ den holstenske By Segeberg og vil paavise, at det navnkundige Folk har hjemme ved Nedre-Elben, muligvis i Holsten. Paa denne Konto kommer Kimbrerne altsaa ind i Hertugdømmernes Historie. Forf. grunder sin Opfattelse paa tre klassiske Hjemmelsmænd, Augustus, Vellejus og Strabon. Augustus siger i 
sin officielle Regerings-Rapport paa Mindesmærket i Ankyra, at han lod sin Flaade sejle fra Rhinen mod Solopgang. Dette er for Scheel Hovedsagen; Ordene skal udelukke en Omsejling af Skagen, thi man kan ikke, stik imod Kejserens Ord, erstatte Østkursen nied en Nordkurs. Dette tilsyneladende slaaende Argument er i Virkeligheden helt forfejlet. Thi, som Skibsreder H. P. Carl gør mig opmærksom paa: under et Flaadetogt om Sommeren ligger "Solens Opgang" ikke mod Øst, men mod Nordøst. Iøvrigt er det tilstrækkeligt at kaste et Blik paa Ptolemaios' Danmarkskort: et for sin Tid saa fortrinligt Kort kan umulig være teguet paa Grundlag af tredjefjerdehaands Meddelelser fra barbariske Skippere; det er nodvendigvis grundet paa en dannet Kartografs førstehaands Iagttagelse, og til en saadan Iagttagelse har der kun været een eneste Lejlighed, nemlig det romerske Flaadetogt til Kimbrernes Land Aar 5 e. Kr. Iøvrigt henviser jeg ti] den udforlige Artikel af mig, som vil fremkomme i "Zeitschrift für schleswig-holsteinische Geschichte« efter Nytaar 1939.

Det hele Sporgsmaal har jo ingen aktuel nationalpolitisk Interesse, men for den folkelige Historiesans har det dog altid nogen Værdi at trænge tilbunds i Spørgsmaalet om de navnkundige Kimbrers Hjemstavn, og derfor har jeg her paapeget, hvor svagt grundede Prof. Scheels lærde Paastande er. Det er ganske ligesom ved hans Paastande om de gamle Ingvæoners Nationalitet og lignende Folkespørgsmaal fra æaldre Tid.

I Tidsskriftet "Volk und Reich«, Særhæfte "Schleswig-Holstein«, 1938, S. 440 ff.-, har Prof. Scheel nu for nylig skrevet en Afhandling om "Herrschafts- und Volkskräfte in der Geschichte Schleswig-Holsteins«. Den giver i korte Omrids Hertugdømmernes Historie fra Urtid til Nutid. Forf. gentager Paastanden om Kimbrernes Hjemmehøren i Elbegnene, uden Svar paa min Kritik i "Flensborg Avis« 21. Maj (som jeg har tilsendt ham). Om Ribe-Overenskomsten 1460 hedder det: "Overfor den kan ikke hævdes, at "Herrerne" havde lavet den. Thi de var Tidens politiske Førere og Ansvarlighedens Bærere. Danske og tyske "Herrer« var komne overens om at slutte den. Ingen var ble- 
ven voldført«. At nævine de danske Herrer forrest er dog noget vildledende. Var der overhovedet Danskere med sammen med de 6-7 holstenske Raader, der sluttede Pagten? Det vilde være rart at vide deres Navne. Og at der ingen Voldførelse skete, er en mild Overdrivelse. Sønderjyske Borgere og Gejstlige havde Aar 1421 udtalt sig for et helt andet "for evig udelt« end det i 1460, nemlig for Sønderjyllands Samhør med Danmark. Af disse Borgere kæmpede Flensborgerne undel Striden med de holstenske Grever til det sidste trofast for den danske Konge, og deres $B y$ erobrede Fjenden kun ved Forræderi af en tysk Flensborger. Alle disse danske voterende sønderjydske Borgere blev i 1460 ikke spurgt; de regnedes som et stumt Vedhæng til deres holstenske Herrer, ligesom Tilfxeldet var med den danske Underklasse ved "Up-ewig-ungedeelt"-Løsenets Genfremdragning i 1815 , hvad Hedemann-Heespen udtrykkelig vidner. Artiklens Slutningsord kan citeres fuldstændig.

»I det nordlige Slesvig stod en Folkegruppe, der i enhver Form og Tydning var gjort fremmed for Ribepagten«. (Havde den nogensinde godkendt den?? G. S-e). "Her var intet af det, der satte den tyske Slesvigholstener i Sving, naar han tænkte paa Landsrettighederne. Her døde alt bort, hvad der mindede om et Fællesskab paa næsten 400 Aar. Siden 1830 var med ufortrøden Møje og Taalmod, der ikke lod sig skræmme af noget, end ikke i de første Aar, da man lange maatte vente paa et livgivende Ekko, bleven vækket en dansk Folkefølelse, som fyldte sig med Ønsket og Viljen til at forenes med Danmark. Især i Smaaborgeres og Smaabønders Krese voxede dette ny Liv frem. Ikke faa stammede fra Indvandrere fra Danmark, 'der havde bosat sig i den nye Stat og var voxet fast. Vi veed endnu ikke, hvor stort Tallet har været. Men Kendsgærningen med en saadan dansk Undervandring ("Unterwanderung ") kan paavises. I de vaktes Hjærter klang fremtidig kun danske Klokker. Over Ribe gik man tilbage til Valdemars Tid. Dannevirke blev Folkerørelsens mægtige Sindbillede, Modstykket til Tyskernes "up ewig ungedeelt«. Et i Danmark indlemmet og til Ejderen naaende Slesvig blev, uden Hensyntagen til 
Nationaliteternes virkelige Stilling i Landet, det politiske Krav. Der blev tegnet et dansk Slesvig, der dog hver evige Dag gencireves af Virkeligheden. En sluttet dansk Folkegruppe fandtes ikke engang i Landets nordlige Egne. Hjemmetyskere, nøjagtig ligesaa hjemmevoxne som Hjemmedanskerne, fandtes lige til Kongeaaen og særlig i Flækkerne og Byerne og i Nordslesvigs sydlige Egne, i de gamle gottorpske Amter. Men Flertallet i Nordslesvig var vakt til et dansk Liv, der fæstnede sig og voxede; ogsaa da i 1864 Ejderdanskernes slesvigske Problem linatte prisgives og afløstes af det nordslesvigske. Dette stadfrstede kun, at den folkelige Adskillelse var fuldbyrdet, og at en Tilbagevenden til den tidligere folkelige ("vorvolkliche«) Tilværelse var ligesaa lidet tænkelig, som en Assimilering af den ene Gruppe med den anden var mulig. Nutildags er der af Nordslesvigs danske Problem opstaaet et hjemmetysk. Overfor den lille danske Folkegruppe syd for den nye Grænse staar en stærk tysk Folkegruppe nord for Grænsen. Haabet om, at den vilde lade sig assimilere, har viist sig illusorisk. Det havde aldrig kunnet dukke op, hvis man havde kendt Hjemmetyskerens Natur. Han forbliver tysk, saa længe han aander. En ud af Folkeidéens Dyb øsende Folkegrupperet, der værner sit Arbejde paa Hjemstavnsgrunden og lader sit tyske Liv udfolde sig frit, i uhæmmet Udvexling med sit eget Folks Liv, maa løse det nye hjemmetyske Problem«.

Den her givne Skildring er jo ganske rolig og nøgtern; men man savner den varme Sympati for det danske Odelsfolk, der saa ofte bryder igennem hos en Hedemann-Heespen. Mindre sympatisk virker ogsaa det forsigtig udtrykte Forsøg paa i væsentlig Grad at aflede den nordslesvigske Folkevækkelse fra kongerigske Indflyttere. Hvem der har læst Lauridsens herlige Bog "Da Sønderjylland vaagnede" og Bladet "Dannevirke«s Jubilæumsskrift, vil vide, hvor skæv denne Synsmaade er. 
For ikke at lade min Gennemgang slutte med afvisende Kritik vil jeg allersidst nævne nogle $\mathbf{i}$ den seneste Tid udkomne tyske Skrifter, som jeg mere eller mindre kan anerkende.

1937 udgav den flensborgske Præst Dr. Carl Matthies e $\mathrm{n}$ "Die deutsche Minderheit in Nordschleswig in Schule und Kirche« (Verlag Leop. Klotz, Leipzig), oversat i »Flensb. Avis«, 18. April; derefter paa Tysk i »Der Schleswiger". Skriftet maa roses højt for sin fornemme Saglighed.

Det hedder deri f. Ex.: „Stridsspørgsmaalene om Vestgermaner og Nordgermaner paa den kimbriske Halvø under Folkevandringen og tidlig Middelalder lades her ude. Uklare Spørgsmaalsstillinger og deraf følgende skæve Svar har yderligere indfiltret og fordunklet det i og for sig vanskelige Spørgsmaalskomplex«. - - I Sandhed vise Ord! Og de rammer særlig Slesvig-Holstenerne, thi i dansk Fremstilling har Vestgermaneriet overhovedet ingen Rolle spillet.

Om Sprogforholdene siger Forf.: "Naar man i det afstaaede Omraade regner 10,000 tysktalende Indbyggere, har man sikkert allerede regnet højt«. - Ogsaa meget ædrueligt. I SlesvigHolstenernes Fantasier er vi vante til helt andre Tal.

Om Striden hedder det: "Der er virkelig ingen Grund til, at slesvigske Landsmænd i aandelig Mening skal slaa deres Hoveder tilblods over deres nationale Forskelle«.

Om dansk Mindretalsret syd for Grænsen hedder det: "Til denne frie Rørighed, der ved en s a a d a n Grænse kun kan billiges og hilses velkommen, har det nye tyske Rige gennem sin Fører givet de grundsætlige Anvisninger, og det danske Mindretal selv har ved forstandig, rolig Holdning gjort sit til, at alvorligere Forstyrrelser er undgaaede. En videre Udvikling i denne Retning vil enhver god Slesviger paa begge Sider Grænsen kun kunne ønske sit Hjemland«.

Vi Danske kan af Hjærtet slutte os til disse smukke Ord. Vi billiger den Anerkendelse, der i dem ydes Føreren Hitlers nabovenlige Initiativ. Ganske vist kan vi til Gengæld ikke 
lukke Øjnene for, at i Øjeblikket tegner Forholdet sig mindre lyst end i 1937.

Sagtens 1937, uden Aarstal, fremkom "Die Nordmark im Glaubenskampf «, udgivet af den kielske Præest J o h a n n es L. or enzen, rettet mod Nyhedningen, den frafaldne Kristenpræst Gustav Frenssen. Heri skriver Pastor J o h a n n es Tonnesen et interessant Stykke "Was der Norden sagt!« S. 69 ff. Han synes at give Frenssen Ret i, at det tyske Slesvig og Holsten er stærkt paa Veje til at afkristnes. Men saa siger han indledende: "Jeg har Ret til at sporge: hører mit tabte Hjem Nordslesvig ikke med til Nordmarken? Thi alt, ja virkelig alt, hvad Frenssen skriver, passer ikke for Nordslesvig. Og ikke blot er det galt, men uforsvarligt. Jeg kan forsikre Fr., at Nordslesvig ikke vedkender sig en Nordmark, der for Folkefølelsen hos Tyske og Danske er en "Vantroens Nordmark «. Jeg kan videre forsikre Fr., at hele det skandinaviske Norden opfatter hans Bog "Der Glaube der Nordmark" som en Stadfæstelse for, at Slesvigs Deling ved Versailles-Diktatet dog har trukket den rette Granse, en Græuse, ved hvilken to Verdener med grundforskelligste Væsensart skilles. Naar Ordet om Folkebroen er sandt, da har Fr. afbrudt denne Bro og anvist vort Land en Plads, der volder dets Mission som Nordmark den sværeste Skade. Han har stængt os af fra Norden! .... Nordmarkens Mission som tysk Fortrop i det tysk-nordiske Mellemværende vilde være i højeste Grad truet, thi den maatte jo nu forsvare sit Særpræg ikke blot mod Norden, men ogsaa mod Syden .... da turde det dog være tilladt at spørge Digteren Frenssen: har du aldrig gjort dig Tanker over Tildragelserne i Grænselandet 1920, der førte til den for vor Historie ufattelige Deling af Slesvig? Er det dig ukendt, at denne Tilskikkelse kun kan forstaas som en Sejr for et $i$ forrige Aarhundredes nordiske Renæssance til nordisk Selvfølelse vakt Folkevæsen over et endnu sovende Folkevæsen, der ikke havde oplevet nogen saadan Vækkelse?«

Derefter taler Pastor Tonnesen smukke Ord om Grundtvigs og Kierkegaards Indsats for Troslivet. 
Til Oplysning om det her sagte maa jeg gribe tilbage til en i 1895 udkommen Bog af Pastor E. A. J e s s e n i Rabsted, "Die Hauptströmungen des religiösen Lebens der Jetztzeit in Dänemark «. Heri hedder det S. 173: "Paa Grund af disse og andre gunstige Vilkaar staar det i Nordslesvig i religiøs-kirkelig Henseende langt bedre til end i Provinsens tysktalende Del«. Dette bliver saa paavist ved talrige Enkeltheder.

Endvidere kan der mindes om, at $\mathrm{J}$ o h. T i e d j e i sin meget omtalte Bog "Die Zustände in Nordschleswig" (1909) karakteriserer det danske Kirkefolk ved Mottoet: "Se, de beder!«

Endelig fortalte Prof. Aage Friis engang $i$ et Foredrag, at en $h ø j t s t a a$ ende preussisk Embedsmand havde tilstaaet til ham: Kristenfolkets Modstand, stottet af frimodige Gejstlige som Tiedje og Joh. S chmidt, var den Klippe, hvorimod den preussiske Tvangspolitiks Stormflod brød virkningsløs sammen.

1937 udgav Folketingsmand Pastor Joh. S ch midt fra Vodder Skriftet "Schicksal, Sendung und Glaube der Nordmark«. Det er en Fremstilling af Nationalitetsproblemet i slesvig-holstensk Lys, og det indeholder Ting, hvori jeg ikke kan være enig med Forf. F. Ex. hævder han S. 30, at Løsenet "Up ewig ungedeelt« 1460 blev udstedt af Ridderskabet som Udtryk for Hertugdømmernes samlede Folk, ikke som Forfægter af specielle Standsinteresser. Her seer Re imer Hansen 1913 og K a r l A l n or i sin Artikel 1919 rigtigere, naar det indrømmes, at Ordene fra 1460 var Udtryk for Standsinteresser og først i Nutiden blev gjort til Folkeløsen. Bortseet derfra er Fremstillingen imidlertid maadeholden, stræber tydelig efter Oprigtighed og nordisk Forstaaelse. Jeg har ovenfor omtalt Pastor Schmidts ridderlige Afvisning af Renegaten Neuhaus' Tilnærmelser.

1937 udgav Dr. Volquard Pa u Is i "Geschichte Schleswig-Holsteins « forste Hæfte af sin Fremstilling af det 12. Aarhundredes Historie. Den hæver sig højt over Gennemsnittet af slesvig-holstenske Skrifter. Der gøres ingen haartrukne Forsøg paa at sammenkoble Slesvig og Holsten i et "vestgermansk" el- 
ler ur-slesvig-holstensk Fællesskab; Slesvig bliver overhovedet knap næevnt. Den saxiske Folkestammes Aggressivitet og den bremisk-hamburgske Arkebispestols Falsknerier i Kampen med Erkebispestolen Lund bliver omtalt uden noget Forsøg paa Tilsløring. Ved den holstenske Rundkirke i Schlamersdorf bliver dansk Kulturindflydelse indrømmet og nærmere paavist. Jfr. min Anm. i "Grænsevagten«, Januar 1938, S. 41.

1937 udgav Larer Paul S e l k »Die sprachlichen Verhältnisse im deutsch-dänischen Sprachgebiet südlich der Grenze«. Dr. phil. Karl Bock siger derom i sin Afhandling "Mellemslesvigs Sprogforhold« i Fr. v. Jessens nye Haandbog, Bd. III, 624. „Selks Arbejde gor et særdeles tilforladeligt Indtryk. Selk er gaaet metodisk og grundigt til Værerks.

Red. Tage Jessen skriver i "Flensborg Avis« 4. 12. 37, at Forf. "utvivlsomt er gaaet til sit Arbejde med det Formaal at fremstille Forholdet mellem Antallet af dansk- og tysktalende saa uhildet som muligt .... Larer Paul selk (er) vistnok kommet Sandheden saa nær, som det er muligt. Han har jo ikke villet lave en af den Slags tendentiøse "Statistikker«, som Forkrigstidens tyske $\Delta$ gitation til Tider opererede med «.

"Modersmaalet" skriver 4. 12. 37, at sselv om man møder Afhandlingen med den mest kritiske Forsigtighed, saa rober den trods sin tyske Tendens dog en hel Del om det danske Sprogs Stilling i Mellemslesvig«.

Iøvrigt skal her ikke gores Rede for Enkelthederne i det meget righoldige og vigtige Materiale, men blot henvises til Dr. Bocks indgaaende Gemnemgang i Haandbogen.

1938 udkom "Zwischen Elbe und Skagerak, Arbeiten über Volkstum und Kultur der cimbrischen Halbinsel«, udg. af Peh der Heinz Carsten. Det er Bd. 3 af "Aus Hansischem Raum, Schriftenreihe der Hansischen Gilde«, og tilegnet Conrad Borchling, »dem Forscher und Lehrer«. Indholdet er: G. S c h w a n tes, "Zur Geschichte der nordischen Zivilisation«; E. Kolumbe og M. Beyle, „Die Bohlwege im Wittmoor (Holstein)«; H. Carsten, »Die cimbrische Halbinsel und ihre Bewohner in frühgeschichtlicher Zeit«; K. H a f f, »Der deut- 
sche Einfluss auf das dänische Recht des Mittelalters«; W. K a estner, "Die platt-deutschen Mundarten in SchleswigHolstein«; H. Hennings en, "Die jütischen Mundarten und Blichers "E Bindstouw«"; W. Flitner, "Grundtvig und die dänische Volkshochschulbewegung«; J. Gebhard, "Die Jütlandsfahrt der Hansischen Gilde zu Hamburg«. De sidstnævnte Artikler ledsages af Billeder af Universitetet i Aarhus, den gamle By og Mindeparken smst., Askov Højskole og Gymnastikskolen i Ollerup etc.

Tonen i Skriftet er helt igennem saglig og tiltalende. Udgiveren Hr. Carsten giver en indgaaende Udredning af Jyllands gamle Geografi og Folkeforhold. Nyt er det, at han tyder Kodanhavet hos Plinius jkke som Østersøen, men som Vesterhavet, henlægger det pliniske Omraade Scadinauja til Nordjylland og tyder det sammesteds nævnte Bjærg Saevo som den jyske Klitkyst. Om denne Opfattelse er rigtig eller gal, skal her ikke drøftes. Talrige Undersøgelser citeres, ogsaa min Bog "Gotthiod und Utgard“; derimod kender Forf. aabenbart ikke min Bog "Our Forefathers" (1929-33), hvori han vilde kunne have fundet adskilligt. Prof. Otto Scheels helt forfejlede Forsøg paa at henlægge Kimbrer og Haruder til Nedreelbens Nabolag ("Gesch. Schleswig-Holsteins" II) nævnes ikke, jfr. min Artikel i »Flensb. Avis« 21. Maj; Forf. tyder uden Tøven Kimbrerne som Himmerboer og Haruderne som Hardsysselboernes Fædre, Anglerne som Indbyggere af Angel. Teutonerne tydes som Tyboer, Ambronerne som Amringer; disse Tydninger kan have deres Rimelighed, men det er næppe sikkert, at den nuværende Stedfæstelse stemmer med den oprindelige. Meget tvivlsom er Varinernes Forbindelse med Warwith (Varde) Syssel og Varnæs, og Vandalernes med Wændle Sysæl og Wændlefolk Hæret; sidstnævnte Identificering er almindelig, men man glemmer, at Egnsnavnet Vendill kunde optræde flere Steder rent spontant, f. Ex. ogsaa i det svenske Upland, og ethvert Egnsfolk fra en Egn Vendill kunde faa Navnet Vandaler. Lignende enslydende Indbyggernavne fra forskellige Egne kendes i Norge. 
Det siges S. 85, at Aabo Syssel ikke finder Genklang i noget Stammenavn; her burde dog have været tilføjet, at Detlefsen har villet forbinde det med det hos Tacitus overleverede Stammenavn Auiones.

Helt uholdbar er Forbindelsen af Kimbrer med sønderjyske Stednavne som Emmerlev og Immervad, og af Ambronerne rred Omungær Syssel i Nørrejylland. De forskellige Retningspile, der skulde vise Stammernes Vandringslinjer paa Kortet S. 110, udsiger ogsaa mere, end vi virkelig veed.

Den sidste Del af Arbejdet, omhandlende Folkeforholdene i Holsten, indeholder sikkert et stort Fond af værdifuld Lokalkundskab, men interesserer os Danske mindre. Jeg noterer S. 99 de to ejendommelige Egnsnavne Sadelbande og Sachsenbande. Forf. synes ikke at lægge Mærke til, at de vistnok indeholder det typisk frankiske Element -b a $n t$, som vi kender fra Brabant; hvis dette er Tilfældet, røber de aabenbart en stærk frankisk Kolonisation, der maa tænkes foretagen efter Karl den Stores Udryddelseskrig mod Saxerne Aar 804.

Endvidere marker vi os, at Forf. ikke deltager i de altfor velkendte, haartrukne Forsøg paa for enhver Pris at nagte Jydernes Tilslutning til Danskerfolket. S. 92 hedder det, at Jylland i historisk Tid er knyttet til Danmark. S. 106 hedder det om Angel: "En virkelig Tilegnelse med Nygrundelse af Landsbyer synes først ved Slutningen af 8 . Aarh. at være foretagen af Danskerne«. "Maaske har der før den afgørende danske Bosættelse i 6.-7. Aarh. fundet en delvis saxisk Indvandring Sted fra Holsten til det gamle angliske Omraade. Dog kan vi hidtil ikke godtgøre denne Formodning «.

S. 107 konstateres efter Adam af Bremen Jydernes Danskhed. Alt i alt maa Forf. roses for sin Uhildethed.

Af Kaestmers Afhandling om de plattyske Mundarter noterer jeg S. 136 Iagttagelsen af angelsaxiske Sproglevn som Assibileringen af $k$ og $g$ i Ord som s e w e $r=t y s k$ «äfer« og je t t "Ged" og i Stednavne som Itzehoe, af Ekeho "Egeskov«. Denne Iagttagelse er vigtig; det kunde blot have været fremhævet 
mere, at her har vi Minder om et oprindelig ikketysk Sprog hos Saxerne i Holsten.

At vor Landsmand Lektor Henningsen har kunnet yde et Bidrag til Værket, maa hilses velkomment. Hans Afhandling om de jyske Maal er ledsaget af mange lærerige Kort; jeg noterer blot, at paa Kortet S. 159 er Vestjysk fejlagtig kommet til at medomfatte Vesthimmerland; i disse Egne hedder det ikke »æ Mand", men "Manden«, og der forekommer kun Tilnærmelser til vestjysk Sprogskik som Vendingen "de Lovns Folk«.

Det hele Værk maa kaldes et smukt Vidnesbyrd om Stræben efter kulturel og sproglig Forstaaelse med de nordiske Stammefrænder.

De i sidste Afdeling nævnte Skrifter danner tilsammen en velgørende Modsætning til, hvad vi ellers møder fra slesv. holstensk Side. Dertil maa endnu føjes HedemannHeespens redelige og uhildede Forskninger i »Die Herzogtümer Schleswig-Holstein und die Neuzeit" 1926, se ovenfor S. 274, og Provinsialkonservator $\mathrm{Rich} . \mathrm{H}$ a u ts Kritik af uheldig dannede Navne som "Østrig-Ungarere" (i Virkeligheden rettet mod Navnet Slesvig-Holstenerne) i "Die Heimat《 1931, se min Artikel "En tysk Sandhedsforkæmper" i "Flensborg Avis«, 14. Januar 1938.

Desværre er Hedemann-Heespen død, og Rich. Haupt følger vel snart efter ham $i$ Graven. Og alt ialt staar de nævnte Mænd blot som Un'ltagelser overfor en i mere end 100 Aar herskende skæv og ensidig Fremstillingsretning. Men vi maa haabe, at der i deres Fodspor maa fremvoxe flere Arvtagere, og at de maa evne at give Tonen an, saa at den af Islændingen Gunnar Gunnarsson i »Der Schleswiger«, December 1937, forfægtede dansk-tyske Forstaaelse endelig kunde blive for Alvor indledet. Et Tegn paa en saadan Udvikling var det, da den tyske Regering nylig optraadte overfor det saakaldte »S k o l i n g s b r e v«, der i Marts Maaned var udsendt til alle nationalsocialistiske Partimedlemmer $\mathrm{i}$ et Oplag af 3 Millioner. Heri opgjordes Tyskerne i Danmark til et alt for højt Tal, 60,000, og paa et med- 
følgende Nationalitetskort var hele den sydlige Trediedel af Nordslesvig afsat med samme mørkerøde Farve som Tyskland, medens tre mørkerøde Striber skød sig frem til Kongeaaen. Baade Text og Kort har de ledende Centralmyndigheder fundet fuldkommen uantagelige for Danmark og i Strid med en ønskelig Forstaaelsespolitik. Hele det udsendte Oplag er derfor blevet konfiskeret, og Skolingsbrevets Ophavsmand er blevet fængslet. Saavidt vides, er en Konfiskering af de officielle Skolingsbreve aldrig før forekommet. Vi maa prise og takke den tyske Regering for denne højsindede Handling. Gid den maa kunne tages som et godt Varsel for F'remtiden! 